\title{
Effects of land use intensity on the full greenhouse gas balance in an Atlantic peat bog
}

\author{
S. Beetz ${ }^{1}$, H. Liebersbach ${ }^{2}$, S. Glatzel ${ }^{1}$, G. Jurasinski ${ }^{1}$, U. Buczko ${ }^{1}$, and H. Höper ${ }^{2}$ \\ ${ }^{1}$ Landscape Ecology and Site Evaluation, University of Rostock, Germany \\ ${ }^{2}$ State Authority for Mining, Energy and Geology, Hanover, Germany
}

Correspondence to: S. Beetz (sascha.beetz@uni-rostock.de)

Received: 15 March 2012 - Published in Biogeosciences Discuss.: 13 June 2012

Revised: 10 January 2013 - Accepted: 19 January 2013 - Published: 15 February 2013

Abstract. Wetlands can either be net sinks or net sources of greenhouse gases (GHGs), depending on the mean annual water level and other factors like average annual temperature, vegetation development, and land use. Whereas drained and agriculturally used peatlands tend to be carbon dioxide $\left(\mathrm{CO}_{2}\right)$ and nitrous oxide $\left(\mathrm{N}_{2} \mathrm{O}\right)$ sources but methane $\left(\mathrm{CH}_{4}\right)$ sinks, restored (i.e. rewetted) peatlands rather incorporate $\mathrm{CO}_{2}$, tend to be $\mathrm{N}_{2} \mathrm{O}$ neutral and release $\mathrm{CH}_{4}$. One of the aims of peatland restoration is to decrease their global warming potential (GWP) by reducing GHG emissions.

We estimated the greenhouse gas exchange of a peat bog restoration sequence over a period of 2 yr (1 July 2007-30 June 2009) in an Atlantic raised bog in northwest Germany. We set up three study sites representing different land use intensities: intensive grassland (deeply drained, mineral fertilizer, cattle manure and 4-5 cuts per year); extensive grassland (rewetted, no fertilizer or manure, up to 1 cutting per year); near-natural peat bog (almost no anthropogenic influence). Daily and annual greenhouse gas exchange was estimated based on closed-chamber measurements. $\mathrm{CH}_{4}$ and $\mathrm{N}_{2} \mathrm{O}$ fluxes were recorded bi-weekly, and net ecosystem exchange (NEE) measurements were carried out every 34 weeks. Annual sums of $\mathrm{CH}_{4}$ and $\mathrm{N}_{2} \mathrm{O}$ fluxes were estimated by linear interpolation while NEE was modelled.

Regarding GWP, the intensive grassland site emitted $564 \pm 255 \mathrm{~g} \mathrm{CO}_{2}-\mathrm{C}$ equivalents $\mathrm{m}^{-2} \mathrm{yr}^{-1}$ and $850 \pm 238 \mathrm{~g} \mathrm{CO}_{2}-\mathrm{C}$ equivalents $\mathrm{m}^{-2} \mathrm{yr}^{-1}$ in the first (2007/2008) and the second (2008/2009) measuring year, respectively. The GWP of the extensive grassland amounted to $-129 \pm 231 \mathrm{~g} \mathrm{CO}_{2}-\mathrm{C}$ equivalents $\mathrm{m}^{-2} \mathrm{yr}^{-1}$ and $94 \pm 200 \mathrm{~g} \mathrm{CO}_{2}-\mathrm{C}$ equivalents $\mathrm{m}^{-2} \mathrm{yr}^{-1}$, while it added up to $45 \pm 117 \mathrm{~g} \mathrm{CO}_{2}-\mathrm{C}$ equivalents $\mathrm{m}^{-2} \mathrm{yr}^{-1}$ and
$-101 \pm 93 \mathrm{~g} \mathrm{CO}_{2}-\mathrm{C}$ equivalents $\mathrm{m}^{-2} \mathrm{yr}^{-1}$ in $2007 / 08$ and 2008/09 for the near-natural site. In contrast, in calendar year $2008 \mathrm{GWP}$ aggregated to $441 \pm 201 \mathrm{~g} \mathrm{CO}_{2}-\mathrm{C}$ equivalents $\mathrm{m}^{-2} \mathrm{yr}^{-1}, 14 \pm 162 \mathrm{~g} \mathrm{CO}_{2}-\mathrm{C}$ equivalents $\mathrm{m}^{-2} \mathrm{yr}^{-1}$ and $31 \pm 75 \mathrm{~g} \mathrm{CO}_{2}-\mathrm{C}$ equivalents $\mathrm{m}^{-2} \mathrm{yr}^{-1}$ for the intensive grassland, extensive grassland, and near-natural site, respectively.

Despite inter-annual variability, rewetting contributes considerably to mitigating GHG emission from formerly drained peatlands. Extensively used grassland on moderately drained peat approaches the carbon sequestration potential of nearnatural sites, although it may oscillate between being a small sink and being a small source depending on inter-annual climatic variability.

\section{Introduction}

The drainage of peatlands for agricultural purposes often induces aerobic conditions that cause increasing carbon dioxide $\left(\mathrm{CO}_{2}\right)$ emissions (Maljanen et al., 2001) and incomplete denitrification, giving rise to enhanced nitrous oxide $\left(\mathrm{N}_{2} \mathrm{O}\right)$ emissions. $\mathrm{N}_{2} \mathrm{O}$ emissions are further increased by the use of fertilizers and manure (Jassal et al., 2011; Maljanen et al., 2010a) on drained peatlands. In contrast, the restoration (i.e. rewetting) of drained peatlands can increase the emission of methane $\left(\mathrm{CH}_{4}\right)$ (Wilson et al., 2009; Saarnio et al., 2009) close to (Tuittila et al., 2000) or even far above (Hargreaves and Fowler, 1998; Laine et al., 2007) the $\mathrm{CH}_{4}$ emission level of natural peatlands. When assessing the overall greenhouse gas (GHG) balance of peatlands, it is important to consider both effects. The mitigation potential for greenhouse gas 
emissions by switching from intensive to extensive grassland use has been a topic of controversial debates for several years (Robertson et al., 2000; Dalal et al., 2007; Schils et al., 2008, and others). Peatland restoration may have huge potentials for reaching internationally agreed sustainability goals, in addition to other beneficial effects regarding nature conservation and ecosystem functions (Gorham and Rochefort, 2003; Zedler and Kercher, 2005; Rochefort and Lode, 2006, and others).

The net ecosystem exchange of $\mathrm{CO}_{2}$ (NEE) between ecosystems and the atmosphere is the difference between two main ecosystem exchange processes. On the one hand, ecosystems incorporate $\mathrm{CO}_{2}$ into biomass via photosynthesis. This is typically expressed as gross primary production (GPP). One of the main driving forces of GPP is photosynthetically active radiation, modulated by the light use efficiency of the plants (Hall and Rao, 1999). On the other hand, ecosystems release carbon into the atmosphere via ecosystem respiration $\left(R_{\mathrm{ECO}}\right)$. $R_{\mathrm{ECO}}$ is mainly controlled by soil temperature (Lloyd and Taylor, 1994) and soil moisture, which is often correlated with the depth of the water table in peatlands (Drösler et al., 2008). The lower the water table, the deeper the aerated soil zone, which results in higher overall intensity of organic matter decomposition.

In contrast, $\mathrm{CH}_{4}$ emissions increase with rising water level since $\mathrm{CH}_{4}$ is mainly produced by methanogenic bacteria that require anaerobic conditions (Dalal and Allen, 2008). $\mathrm{CH}_{4}$ production also depends on temperature (Bellisario et al., 1999; Blodau, 2002). Thus, when rewetting deeply drained grassland sites there is an optimum water level at which the overall production of $\mathrm{CO}_{2}$ and $\mathrm{CH}_{4}$ is minimized. For example, Jungkunst et al. (2008) found this optimum at mean annual water levels around $-5 \mathrm{~cm}$.

$\mathrm{N}_{2} \mathrm{O}$ develops in peatlands as a by-product of both nitrification and denitrification (Kasimir-Klemedtsson et al., 1997), but emission rates are generally low compared to agricultural areas. In many GHG balance studies, $\mathrm{N}_{2} \mathrm{O}$ is neglected because of $\mathrm{N}$-poor conditions in natural peat bogs on which most of the conceptual models of peatland biogeochemistry are based (Teh et al., 2011). However, managed peatlands often have enhanced N-pools and cycling rates due to fertilization or manuring. Therefore, they have a much higher potential for $\mathrm{N}_{2} \mathrm{O}$ emissions than natural peatlands. Several studies address the $\mathrm{N}_{2} \mathrm{O}$ exchange of managed peatlands (see review of Jungkunst and Fiedler, 2007) and published annual nitrous oxide emissions from managed peatlands range between $0.4 \mathrm{~g} \mathrm{~N} 2 \mathrm{O}-\mathrm{N} \mathrm{m}^{-2} \mathrm{yr}^{-1}$ (for a threecut grassland site with only mineral fertilizing, Flessa et al., 1998 ) and $2.0 \mathrm{~g} \mathrm{~N}_{2} \mathrm{O}-\mathrm{N} \mathrm{m}^{-2} \mathrm{yr}^{-1}$ (as a mean for farmed organic soils in the Netherlands, Kasimir-Klemedtsson et al., 1997).

The contribution of peatlands to the atmospheric GHG budget has been addressed in several studies (Kettunen et al., 1999; Drösler et al., 2008; Ojanen et al., 2010 and others). The majority of these address either drained or natu- ral boreal peatlands, whereas data from the temperate zone and comparisons between drained and natural peatlands are still scarce (e.g. Hendriks et al., 2007; Wilson et al., 2007; Couwenberg, 2011). The same holds for full GHG balances of peatland ecosystems including the exchange of all three major GHG. These are also mainly available for peatlands in nordic countries (Alm et al., 1999, 2007; Maljanen et al., 2010b, and others) but are scarce for the temperate zone. The available studies combine eddy covariance and closed chamber measurements, but they do not account for different land use intensities. It was shown that GHG emissions vary greatly between years (Jungkunst et al., 2006; Iqbal et al., 2009). Thus, investigations spanning more than one year are crucial to provide reliable data, which may allow for the upscaling of GHG emissions to the regional scale, e.g. as a basis for the estimation of the contribution of peatlands to countrywide GHG balances.

Here, we provide full greenhouse gas balances of raised bogs with different degrees of land use intensity (1: intensively used, 2: extensively used, 3: undisturbed near-natural), based on two years of $\mathrm{CO}_{2}, \mathrm{CH}_{4}$, and $\mathrm{N}_{2} \mathrm{O}$ closed-chamber measurements in a peat bog complex in northern Germany.

We hypothesize that extensive grassland use on rewetted peatland leads to a decrease in global warming potential (GWP) when compared to intensively used grassland on non-rewetted peatland. The GWP is a relative measure expressing how much heat GHGs trap in the atmosphere in relation to $\mathrm{CO}_{2}$ based on conversion factors (e.g. Forster et al., 2007). Due to the raised water table and a shallow aerated soil layer (acrotelm), $\mathrm{CO}_{2}$ emissions are expected to decrease while $\mathrm{CH}_{4}$ emissions are expected to increase, whereas $\mathrm{N}_{2} \mathrm{O}$ emissions should decrease to a near-natural level due to the lack of fertilizer and manure additions.

\section{Material and methods}

\subsection{Study area}

The study area is located approximately $80 \mathrm{~km}$ northwest of Hamburg at $53^{\circ} 41^{\prime} \mathrm{N}$ and $8^{\circ} 49^{\prime} \mathrm{E}$ in the "Ahlen-Falkenberger Moor" peat bog complex, which is about $20 \mathrm{~km}$ from the North Sea coast (Fig. 1). The climate is humid Atlantic with an average annual precipitation of $925.7 \mathrm{~mm}$ and an average annual temperature of $8.5^{\circ} \mathrm{C}$ (reference period 1961-1990; German Weather Service, 2010). Under such conditions, natural soil formation processes lead to fens and peat bogs in poorly drained areas (Schneekloth, 1981).

The Ahlen-Falkenberger Moor is one of the largest peat bog complexes in Lower Saxony between the estuaries of the Elbe and Weser rivers. Many parts of the peat bog complex have been drained for peat extraction since the late 17th century and cultivated for intensive grassland use since the 1950 s. About $60 \%$ of the whole area is currently used as grassland. A small part in the centre of the peat bog complex 


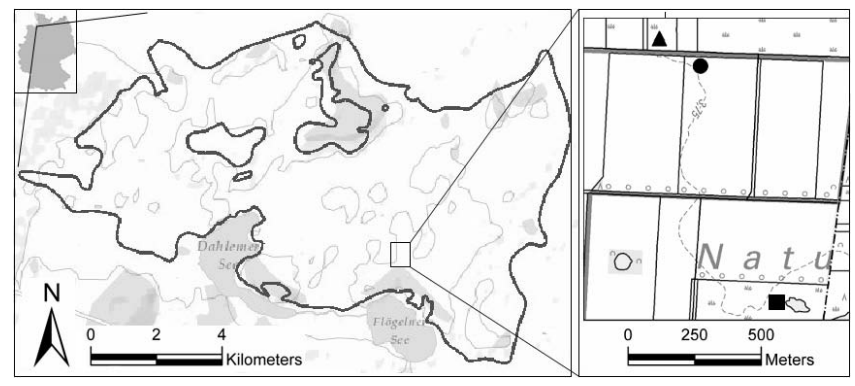

Fig. 1. Location of the Ahlen-Falkenberger peat bog within Germany (upper left small map), and the sites within the inner peat bog complex of the Ahlen-Falkenberger peat bog (left map). On the right map the black triangle ( $\mathbf{\Lambda}$ ) denotes the extensively used site (GE), the circle $(\bullet)$ the intensively used one (GI), and the square $(\boldsymbol{\square})$ the natural one within a nature reserve area (NW) (LGLN, 2012).

(approx. 5\%) was never drained or cultivated and remains natural peat bog today (Höper, 2007). In this area vegetation is dominated by cross-leaved heath (Erica tetralix L.), flat-topped bog moss (Sphagnum fallax Klinggr.), and common cottongrass (Eriophorum angustifolium Honck.). Peat depths range from $330 \mathrm{~cm}$ in cultivated areas to $515 \mathrm{~cm}$ in uncultivated, near-natural areas. The peat in the cultivated areas contains $5 \%$ cottongrass and $1 \%$ heather remnants in the upper layer. It is strongly humified down to $15 \mathrm{~cm}$ and poorly humified down to $140 \mathrm{~cm}$ (Table 1). Atmospheric reactive nitrogen $(\mathrm{N})$ deposition in the region ranges from 2.2 to $2.5 \mathrm{~g} \mathrm{~N} \mathrm{~m}^{-2} \mathrm{yr}^{-1}$ (Schröder et al., 2011).

We set up three measurement sites in parts of the peat bog complex with differing land use intensities (Table 1): The intensive grassland (GI) site is managed by $4-5$ cuts per year and both mineral fertilization $\left(11.8 \mathrm{~g} \mathrm{~N} \mathrm{~m}^{-2} \mathrm{yr}^{-1}\right.$ in $2008,12.1 \mathrm{~g} \mathrm{~N} \mathrm{~m}^{-2} \mathrm{yr}^{-1}$ in 2009) and manure application $\left(226 \mathrm{~g} \mathrm{C} \mathrm{m}^{-2} \mathrm{yr}^{-1}\right.$ in $2008\left(2.3 \mathrm{tC} \mathrm{ha}^{-1} \mathrm{yr}^{-1}\right)$, $206 \mathrm{~g} \mathrm{C} \mathrm{m}^{-2} \mathrm{yr}^{-1}$ in $\left.2009\left(2.1 \mathrm{tC} \mathrm{ha}^{-1} \mathrm{yr}^{-1}\right)\right)$. The extensively used grassland site (GE) is neither manured nor fertilized and only cut up to once per year. The site was rewetted in 2003/2004. The natural wetland (NW) site is located in a nature reserve area without any drainage or land cultivation. At each site, three square PVC collars $(0.75 \mathrm{~m} \times 0.75, \mathrm{~m} \times 0.15 \mathrm{~m})$ were permanently installed sharing minimum distances of $3 \mathrm{~m}$. A boardwalk was installed to avoid disturbances during measurements. The positions of the plots were chosen to best represent the variation in environmental conditions and vegetation at the sites (Fig. 1).

\subsection{GHG measurements and gas flux calculation}

We determined $\mathrm{CO}_{2}$ exchange from 1 July 2007 until 30 June 2009 in 3 to 4 week intervals. Overall we conducted 29 measurement campaigns during these two years using square, closed chambers $(0.78 \mathrm{~m} \times 0.78 \mathrm{~m} \times 0.5 \mathrm{~m})$ in through-flow (dynamic) mode. Opaque and transparent chambers were placed in turn to obtain data on combined autotrophic and heterotrophic respiration of the ecosystem $\left(R_{\mathrm{ECO}}\right)$ and net ecosystem exchange (NEE), respectively, following the method of Drösler (2005); see Elsgaard et al. (2012) for a similar approach. Measurements started at sunrise and continued until late afternoon, when soil temperature at $5 \mathrm{~cm}$ depth generally reached its maximum value. Up to 72 transparent and 42 opaque measurements were taken over the course of one day (cf. Tables A1, A2, A3 for GI, GE, and $\mathrm{NW}$, respectively). Each measurement lasted no longer than $120 \mathrm{~s}$ for the transparent chamber and $240 \mathrm{~s}$ for the opaque chambers. Following this procedure, the largest possible daily range of the main drivers of $\mathrm{CO}_{2}$ exchange - photosynthetically active radiation (PAR) and soil temperature was covered. $\mathrm{CO}_{2}$ concentrations within the chambers were determined with an infrared gas analyser (IRGA; LI-820 ${ }^{\mathrm{TM}}$, Licor $^{\circledR}$, Lincoln, NE, USA). To prevent heating and to ensure thorough mixing of the air in the chamber headspace, the transparent chamber was equipped with two fans that ran continuously during measurements. Additionally, freezer packs were positioned on a frame inside the chamber. With this cooling system, heating of the chamber during measurements was less than $+1.5^{\circ} \mathrm{C}$ with respect to the outside air temperature.

We measured $\mathrm{CH}_{4} / \mathrm{N}_{2} \mathrm{O}$ fluxes bi-weekly from July 2007 through June 2009 using opaque chambers. We mixed the air inside the chamber by flushing with a $60 \mathrm{~mL}$ syringe shortly before gas sampling, which took place 0, 20, 40 and $60 \mathrm{~min}$ following chamber closure. The samples were immediately transferred to an evacuated, airtight, custom-made $20 \mathrm{~mL}$ glass vial (Hassa, Lübeck, Germany). The gas analysis was done using a gas chromatograph (Finnigan Trace GC Ultra with Finnigan Valve Oven Trace GC Ultra, Thermo Fisher Corp.) equipped with a flame ionization detector for $\mathrm{CH}_{4}$ analysis and an electron capture detector for analysis of $\mathrm{N}_{2} \mathrm{O}$ concentrations. The precision of analysis for $\mathrm{CH}_{4}$ and $\mathrm{N}_{2} \mathrm{O}$ was $3-4 \%$ and $4-5 \%$ respectively, as determined by replicate injections of calibration gas with ambient concentrations of $\mathrm{N}_{2} \mathrm{O}$ and $\mathrm{CH}_{4}$.

\subsection{Environmental parameters}

Nylon-coated tubes were installed at each plot for monitoring water levels. The tubes were $5 \mathrm{~cm}$ wide and perforated in their lower halves, and they were equipped with filter slots and a cap at the bottom to prevent water discharge. We recorded water levels every 2 weeks during gas sampling campaigns with an electric contact gauge. Furthermore, we recorded PAR in $0.5 \mathrm{~m}$ height above ground and soil temperature at $5 \mathrm{~cm}$ depth nearby the sites with additional sensors during the measuring days. We installed a climate station close to the three sites to record half-hourly readings of photosynthetically active radiation (PAR) in $2 \mathrm{~m}$ height, air temperature and air humidity in $0.2 \mathrm{~m}$ height, as well as precipitation in $1 \mathrm{~m}$ height above ground. The soil temperature 
Table 1. Soil and land use characteristics of the research sites in the Ahlen-Falkenberger peat bog.

\begin{tabular}{llllllll}
\hline Site & $\begin{array}{l}\text { Peat } \\
\text { depth } \\
(\mathrm{cm})\end{array}$ & $\begin{array}{l}\text { Peat } \\
\text { state }\end{array}$ & $\begin{array}{l}\text { Land } \\
\text { use }\end{array}$ & $\begin{array}{l}\mathrm{C} / \mathrm{N} \\
\text { ratio* }\end{array}$ & $\mathrm{pH}$ & Fertilization & $\begin{array}{l}\text { Vegetation } \\
\text { (dominant } \\
\text { species) }\end{array}$ \\
\hline GI & 330 & degraded & $\begin{array}{l}\text { intensive } \\
\text { grassland }\end{array}$ & 22.2 & 3.39 & $\begin{array}{l}\text { mineral fertilizer, } \\
\text { cattle manure }\end{array}$ & $\begin{array}{l}\text { Anthoxanthum odoratum } \text { L., } \\
\text { Lolium perenne } \text { L. }\end{array}$ \\
\hline GE & 340 & degraded & $\begin{array}{l}\text { extensive } \\
\text { grassland }\end{array}$ & 21.2 & 3.27 & none & $\begin{array}{l}\text { Juncus effusus } \text { L., } \\
\text { Anthoxanthum odoratum } \text { L. }\end{array}$ \\
\hline NW & 515 & $\begin{array}{l}\text { near- } \\
\text { natural }\end{array}$ & none & 27.7 & 3.05 & none & $\begin{array}{l}\text { Eriophorum angustifolium } \text { Honck, } \\
\text { Sphagnum fallax } \text { Klinggr. }\end{array}$ \\
\hline
\end{tabular}

* Displayed is the ratio of the uppermost peat layer, mostly $0-15 \mathrm{~cm}$ depth.

was monitored half-hourly at the position of the climate station in $5 \mathrm{~cm}$ depth.

\subsection{Data analysis}

\subsubsection{Flux determination}

Gas fluxes were calculated using the slope of gas concentrations over time:

$F=k \frac{273.15}{T} \frac{V}{A} \frac{\Delta c}{\Delta T}$,

with $F$ the calculated flux $\left(\mathrm{mg} \mathrm{CO}_{2}-\mathrm{C} \mathrm{m}^{-2} \mathrm{~h}^{-1}, \mu \mathrm{g} \mathrm{CH}_{4}-\right.$ $\mathrm{C} \mathrm{m}^{-2} \mathrm{~h}^{-1}$ or $\left.\mu \mathrm{g} \mathrm{N} \mathrm{N}_{2} \mathrm{O}-\mathrm{N} \mathrm{m}^{-2} \mathrm{~h}^{-1}\right), k$ a unit conversion factor for calculating fluxes $\left(0.536 \mathrm{~kg} \mathrm{C} \mathrm{m}^{-3}\right.$ for $\mathrm{CH}_{4}$ and $\mathrm{CO}_{2}$ and $1.25 \mathrm{~kg} \mathrm{~N} \mathrm{~m}^{-3}$ for $\mathrm{N}_{2} \mathrm{O}$, modified after Flessa et al., 1998), $T$ the mean temperature inside the chamber (K), $V$ the total volume of the chamber in $\mathrm{m}^{3}, A$ the area of the collar $\left(0.5625 \mathrm{~m}^{2}\right)$, and $\Delta c \Delta t^{-1}$ the concentration change in the chamber headspace over time $\left(\mathrm{CO}_{2}: \mathrm{ppm} \mathrm{h}^{-1}, \mathrm{CH}_{4}\right.$ and $\mathrm{N}_{2} \mathrm{O}$ : $\mathrm{ppbh}^{-1}$ ).

Net ecosystem exchange (NEE) of $\mathrm{CO}_{2}-\mathrm{C}$ represents a mixed signal that results from the simultaneous processes of $\mathrm{CO}_{2}$ uptake via photosynthesis (gross primary production GPP) and the emission of $\mathrm{CO}_{2}$ to the atmosphere by ecosystem respiration $\left(R_{\mathrm{ECO}}\right)$ (Chapin et al., 2006):

$\mathrm{NEE}=\mathrm{GPP}+R_{\mathrm{ECO}}$.

We followed the atmospheric sign convention: all C fluxes into the ecosystem are defined as negative (uptake from the atmosphere into the ecosystem), whereas all $\mathrm{C}$ fluxes from the ecosystem to the atmosphere are defined as positive. This holds also for non-atmospheric inputs like manure application (negative sign) and outputs like cutting (positive sign). As a consequence, NEE can be positive (emission or release of $\mathrm{CO}_{2}-\mathrm{C}$ from the ecosystem) or negative (uptake of $\mathrm{CO}_{2}-$ $\mathrm{C}$ by the ecosystem) depending on the values of GPP and $R_{\mathrm{ECO}}$.

\subsection{2 $R_{\text {ECO }}$ modelling}

$R_{\text {ECO }}$ can be modelled following different approaches (Maljanen et al., 2001; Wilson et al., 2007). We used the Arrhenius type model of Lloyd and Taylor (1994) to estimate the parameters $R_{\text {ref }}$ and $E_{0}$ for each measurement campaign Eq. (3):

$R_{\mathrm{ECO}}=R_{\mathrm{ref}} \exp \left\{E_{0}\left(\frac{1}{T_{\mathrm{ref}}-T_{0}} \frac{1}{T_{\text {soil }}-T_{0}}\right)\right\}$,

with $R_{\mathrm{ECO}}$ the measured ecosystem respiration rate $\left(\mathrm{mg} \mathrm{CO}_{2}-\mathrm{C} \mathrm{m}^{-2} \mathrm{~h}^{-1}\right), R_{\text {ref }}$ the respiration at reference temperature $\left(\mathrm{mg} \mathrm{CO}_{2}-\mathrm{C} \mathrm{m}^{-2} \mathrm{~h}^{-1}\right), E_{0}$ an activation like parameter $(\mathrm{K}), T_{\text {ref }}$ the reference temperature $(283.15 \mathrm{~K}), T_{0}$ the temperature constant for the start of biological processes $(227.13 \mathrm{~K})$, and $T_{\text {soil }}$ the soil temperature in $5 \mathrm{~cm}$ depth $(\mathrm{K})$. When it was not possible to calculate a significant relationship between $R_{\mathrm{ECO}}$ and $T_{\text {soil5 }}$ from the data of one measuring day we pooled the data of two measuring days to establish a significant relationship that allowed for the fitting of the $R_{\mathrm{ECO}}$ model. Using the campaign specific parameters $R_{\mathrm{ref}}$ and $\mathrm{E}_{0}$ we estimated $R_{\mathrm{ECO}}$ at the times of the NEE chamber measurements and subtracted it from the measured NEE values to obtain GPP values.

\subsubsection{GPP modelling}

The relationship between the uptake of $\mathrm{CO}_{2}$ by plants (GPP) and photosynthetically active radiation (PAR) can be modelled using the Michaelis-Menten-kinetics (Michaelis and Menten, 1913) and is known to vary greatly between plant species and individual plant development stages (Hall and Rao, 1999). Therefore, we estimated the parameters $\alpha$ (initial slope of the regression curve in $\mathrm{mg} \mathrm{CO}_{2}-$ $\left.\mathrm{C} \mathrm{m}^{-2} \mathrm{~h}^{-1}\right) /\left(\mu \mathrm{mol} \mathrm{m} \mathrm{m}^{-2} \mathrm{~s}^{-1}\right.$ ) and $\mathrm{GP}_{\max }$ (limit of production rate when approaching infinite PAR in $\mathrm{mg} \mathrm{CO}_{2}-\mathrm{C} \mathrm{m}^{-2} \mathrm{~h}^{-1}$ ) for each measurement location per measurement date using Eq. (4):

$\mathrm{GPP}=\frac{\mathrm{GP}_{\max } \cdot \alpha \cdot \mathrm{PAR}}{\mathrm{GP}_{\max }+\alpha \cdot \mathrm{PAR}}$, 
with PAR the photon flux density of the photosynthetically active radiation $\left(\mu \mathrm{mol} \mathrm{m} \mathrm{m}^{-2} \mathrm{~s}^{-1}\right)$. We then used these parameters to estimate half-hourly GPP values. Between measurement dates the plant biomass develops and we assumed a linear development of the model parameters $\alpha$ and $\mathrm{GP}_{\max }$ between campaigns. Additionally, we set them back to $-0.0001 \mathrm{mg} \mathrm{CO}_{2}-\mathrm{C} \mathrm{m}^{-2} \mathrm{~h}^{-1} /\left(\mu \mathrm{mol} \mathrm{m}{ }^{-2} \mathrm{~s}^{-1}\right)$ and $-0.01 \mathrm{mg} \mathrm{CO}_{2}-\mathrm{C} \mathrm{m}^{-2} \mathrm{~h}^{-1}$ when the vegetation was cut to represent the loss of green biomass that sets back the ability of the plants to take up $\mathrm{CO}_{2}$ from the atmosphere. The required half-hourly values of PAR (for modelling GPP) and $T_{\text {soil5 }}$ (for modelling $R_{\mathrm{ECO}}$ ) were provided by the climate station to calculate half-hourly values of GPP and $R_{\mathrm{ECO}}$ and, using Eq. (2), NEE values. These were summed up to daily values $\left(\mathrm{g} \mathrm{CO}_{2}-\mathrm{C} \mathrm{m}^{-2} \mathrm{~d}^{-1}\right)$ for all later analyses.

Because the models were fitted per campaign to better capture the phenological development of vegetation, it occurred occasionally that the explaining variables PAR and $T_{\text {soil5 }}$ were outside the range for which the model was valid, leading to unrealistic estimations for $R_{\mathrm{ECO}}$ and thus GPP and NEE. Therefore, we detected outliers in the daily sums of $R_{\mathrm{ECO}}$ and GPP and removed unrealistic values from the dataset. To do so we grouped the dataset into growing and non-growing seasons depending on the temperature sums of the climate station record (following Janssens, 2010), calculated the interquartile range (IQR) of every subset and removed all values $>1.5 \times \mathrm{IQR}$ of the higher quartile and $<1.5 \times$ IQR of the lower quartile (Tukey, 1977). The resulting data gaps were filled by linear interpolation between the marginal data points enclosing the gap. All statistical analyses were done using the software package R 2.15.0 (R Development Core Team, 2012).

$\mathrm{CH}_{4}$ and $\mathrm{N}_{2} \mathrm{O}$ fluxes per site and measurement date were calculated together with the standard deviation of the three replicates using equation (1). Only fluxes significantly different from zero were taken into account (t-test with alpha $=0.05$ ). Annual emission sums were then estimated by linear interpolation between the single measurement dates and summation of daily values.

\subsubsection{Definitions}

To include all $\mathrm{C}$ inputs and outputs into and from our sites, the net ecosystem carbon balance (NECB) was calculated, which is defined as the net rate of $\mathrm{C}$ accumulation (or release) in (or from) ecosystems. This includes all physical, biological and anthropogenic sources and sinks (Chapin et al., 2006). Here, we used a simplified version comprising the gaseous fluxes of $\mathrm{CO}_{2}$ and $\mathrm{CH}_{4}$ as well as $\mathrm{C}$ accumulation and loss via manure and cutting similar to the approach of Elsgaard et al. (2012) and followed the atmospheric sign convention for $\mathrm{C}$ exchange (see above). Note that Chapin et al. (2006) use the opposite sign convention.

Like with NECB the set system boundaries determine what is included in the GWP. Here we include the sum of
$\mathrm{C}$ import (via manuring), $\mathrm{C}$ export (via cutting), NEE and the exchange of $\mathrm{CH}_{4}-\mathrm{C}$ and $\mathrm{N}_{2} \mathrm{O}-\mathrm{N}$. The contribution of the latter was calculated using the 2007 IPCC standards (Forster et al., 2007) with a radiative forcing factor of 25 for $\mathrm{CH}_{4}$ and 298 for $\mathrm{N}_{2} \mathrm{O}$ related to $\mathrm{CO}_{2}$, and a time horizon of $100 \mathrm{yr}$. These factors were converted using the atomic mass of the elements $\mathrm{C}$ and $\mathrm{N}$ for methane and nitrous oxide, respectively, to get atomic mass based factors ( 9.1 and 127.7 for $\mathrm{CH}_{4}-\mathrm{C}$ and $\mathrm{N}_{2} \mathrm{O}-\mathrm{N}$, respectively).

Many studies cover only one year (e.g. Hendriks et al. 2007) and do not cover a calendar year (e.g. Veenendaal et al., 2007; Lund et al., 2007). However, due to inter-annual variability, different integration periods may lead to considerable differences in the derived annual budgets. To evaluate the influence of the integration period on the estimated global warming potential, we calculated annual budgets using a 365-day shifting window beginning with 2007/07/01 until 2008/07/01.

\subsection{Uncertainty analysis}

Estimating total uncertainties of the annual estimates of $R_{\mathrm{ECO}}$, GPP, and NEE is challenging because there are multiple sources of error with varying degree of conceivability. Besides the model error, the uncertainty arising from extrapolating the model parameters in time is surely of major importance. Therefore, we include both these errors when estimating the total uncertainty following these three steps:

First, we estimated the model error. To do so, we calculated the standard errors (SE) per measurement campaign for the locally fitted $R_{\mathrm{ECO}}$ and GPP regression. The SE takes into consideration the uncertainty due to spatial variation (i.e. between the three replicates) and the uncertainty due to variation in the measurement conditions, e.g. precision of the $\mathrm{CO}_{2}$ analysis with the portable IRGA, handling of the chambers, and short-term changes in environmental conditions other than temperatures and PAR. The daily SEs were cumulated for periods around a given measurement day starting and ending midways between the precedent and antecedent measurement days, respectively. The total model uncertainty of the annual estimates was then calculated following the law of error propagation as the square root of the sum of the squared SE of the SE accumulation periods. This model uncertainty is based on the same data points that were used for fitting the model, which may lead to slight underestimations. However, the number of chamber-based measurements was too small to capture seasonal variability, yet still to be split into separate subsets for fitting and validation.

Second, we developed a bootstrap permutation procedure (Efron and Tibshirani, 1993) to estimate the uncertainty resulting from linearly interpolating the model parameters between campaigns. To do so we excluded 4 randomly chosen models from every annual dataset and then calculated the annual balance without them following the approach described above. This routine was repeated 1000 times, yielding 1000 
annual estimates. We calculated the standard deviation of these annual estimates to obtain the uncertainty estimate. Standard gap-filling techniques for quasi-continuous flux data derived from eddy covariance measurements (e.g. Moffat et al. 2007) cannot be adapted to chamber measurements because data are too sparse. However, by randomly leaving out campaign data we simulate varying gap lengths between campaigns and quantify the influence of the interpolation on the uncertainty of the annual estimate.

Finally, we estimated the total uncertainty of the annual estimates (displayed in Table 2) following the law of error propagation from the values calculated in the 1 st and 2 nd step. A complete list of all model parameters and standard errors are compiled in Tables A1, A2, A3 of the Appendix for GI, GE, and NW, respectively. The uncertainty of data from the weather station was not taken into account.

\section{Results}

\subsection{Weather conditions}

During the study period, mean annual air temperatures were higher $\left(10.2^{\circ} \mathrm{C}\right.$ in $07 / 08$ and $08 / 09,10.8^{\circ} \mathrm{C}$ in 2008) than the long-term average $\left(8.5^{\circ} \mathrm{C}\right)$ of the period $1961-1990$. Precipitation was slightly lower in the first period $(916 \mathrm{~mm}$ in 07/08), slightly higher in the second period $(929 \mathrm{~mm}$ in 08/09), and even higher when summed up for the calendar year $2008(1024 \mathrm{~mm})$ than the long-term average annual precipitation $(926 \mathrm{~mm})$. Fig. 2 shows the seasonal distribution of monthly mean air temperatures and precipitation sums.

\subsection{Carbon exchange}

\subsubsection{Gross primary production (GPP)}

The GPP showed a clear seasonal pattern with maximum uptake rates in the summer months. The highest daily $\mathrm{CO}_{2}-\mathrm{C}$ fixation rates occurred during July on all sites (Fig. 3). In the intensively used grassland site (GI), the highest $\mathrm{CO}_{2}-\mathrm{C}$ uptake was modelled for 24 July $2008\left(-16.2 \pm 1.8 \mathrm{~g} \mathrm{CO}_{2}-\right.$ $\mathrm{C} \mathrm{m}^{-2} \mathrm{~d}^{-1}$ ). At the other two sites, highest $\mathrm{CO}_{2}-\mathrm{C}$ uptakes were modelled for July 2007. In the extensively used grassland site (GE) and the near-natural site (NW), highest $\mathrm{CO}_{2}-$ $\mathrm{C}$ uptake occurred on 8 July 2007 with $-10.8 \pm 2.5 \mathrm{~g} \mathrm{CO}_{2}-$ $\mathrm{C} \mathrm{m}^{-2} \mathrm{~d}^{-1}$ and $-6.1 \pm 1.2 \mathrm{~g} \mathrm{CO}_{2}-\mathrm{Cm}^{-2} \mathrm{~d}^{-1}$. All values are displayed with their model error.

\subsubsection{Ecosystem respiration $\left(\boldsymbol{R}_{\mathrm{ECO}}\right)$}

Like GPP, $R_{\mathrm{ECO}}$ revealed a seasonal pattern with maximum peaks during the summer months of both years. The highest daily ecosystem respiration rates occurred during July (16 to 19 in 2007) at all sites: GI, GE and NW released $20 \pm 0.8 \mathrm{~g} \mathrm{CO}_{2}-\mathrm{C} \mathrm{m}^{-2} \mathrm{~d}^{-1}, 7.7 \pm 0.9 \mathrm{~g} \mathrm{CO}_{2}-\mathrm{C} \mathrm{m}^{-2} \mathrm{~d}^{-1}$ and

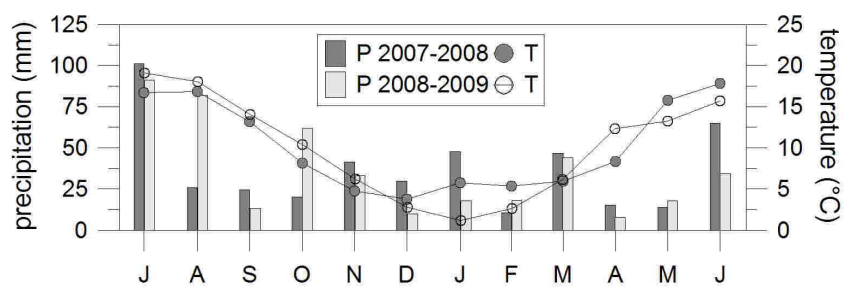

Fig. 2. Monthly values of precipitation and air temperature of both years in comparison. Both years do not differ significantly (permutation test) with regard to bulk annual values of these two variables, although considerable differences between some months did occur.

$6.7 \pm 0.4 \mathrm{~g} \mathrm{CO}_{2}-\mathrm{C} \mathrm{m}^{-2} \mathrm{~d}^{-1}$, respectively. All values are displayed with their model error.

\subsubsection{Net ecosystem carbon balance (NECB) and Net ecosystem exchange (NEE)}

According to the NECBs, the GI site was the biggest source of carbon in both years with $548 \pm 255 \mathrm{~g} \mathrm{CO}_{2-}$ $\mathrm{C} \mathrm{m}^{-2} \mathrm{yr}^{-1}$ and $817 \pm 238 \mathrm{~g} \mathrm{CO}_{2}-\mathrm{C} \mathrm{m}^{-2} \mathrm{yr}^{-1}$, respectively. However, when considering only NEE - without accounting for cutting, manuring and methane exchange - the years did not differ significantly (permutation test, significance of difference of means $=0.33$ ). The GE site was neutral with an annual NEE of $-148 \pm 231 \mathrm{~g} \mathrm{CO}_{2}-$ $\mathrm{C} \mathrm{m}^{-2} \mathrm{yr}^{-1}$ in the first year and $88 \pm 200 \mathrm{~g} \mathrm{CO}_{2}-\mathrm{C} \mathrm{m}^{-2} \mathrm{yr}^{-1}$ in the second year. In contrast, the NW site neither stored nor released in the first year and accumulated $\mathrm{CO}_{2}-\mathrm{C}$ in the second year with an NEE of $-8 \pm 116 \mathrm{~g} \mathrm{CO}_{2-}$ $\mathrm{C} \mathrm{m}^{-2} \mathrm{yr}^{-1}$ and $-127 \pm 92 \mathrm{~g} \mathrm{CO}_{2}-\mathrm{C} \mathrm{m}^{-2} \mathrm{yr}^{-1}$, respectively (Fig. 3, Table 2). In 2008 only the GI site emitted $434 \pm 201 \mathrm{~g} \mathrm{C} \mathrm{m}^{-2} \mathrm{yr}^{-1}$ regarding the NECB. Both other sites acted neutrally with $1 \pm 162 \mathrm{~g} \mathrm{C} \mathrm{m}^{-2} \mathrm{yr}^{-1}$ at the GE site, and $-9 \pm 75 \mathrm{~g} \mathrm{C} \mathrm{m}^{-2} \mathrm{yr}^{-1}$ at the NW site.

\subsection{Methane exchange}

Hourly methane emissions were highest at the NW site followed by the GE site, whereas the GI site exhibited the lowest methane emissions (Fig. 4). The NW site showed a seasonal emission pattern with peaks in the beginning of autumn in 2007 and 2008 as well as in spring 2008. However, emissions did not peak in spring of 2009. In contrast, the GI site exhibited clear positive and negative peaks only during winter 2007/08, whereas the emissions from the GE site showed two relatively distinct peaks (compared to the otherwise low to zero fluxes from that site) in July 2007 and a continuous release of methane during winter 2007/08.

Annual methane fluxes were small on the GI site with $146 \pm 354 \mathrm{mg} \mathrm{CH}_{4}-\mathrm{Cm}^{-2} \mathrm{yr}^{-1}$ in $2007 / 08$ and $73 \pm 51 \mathrm{mg} \mathrm{CH}_{4}-\mathrm{C} \mathrm{m}^{-2} \mathrm{yr}^{-1}$ in 2008/09 (Table 2). The GE site emitted more with $1518 \pm 740 \mathrm{mg} \mathrm{CH}_{4}-\mathrm{C} \mathrm{m}^{-2} \mathrm{yr}^{-1}$ in $2007 / 08$ and $261 \pm 133 \mathrm{mg} \mathrm{CH}_{4}-\mathrm{Cm}^{-2} \mathrm{yr}^{-1}$ in 2008/09. 
Table 2. Annual components (ecosystem respiration $R_{\mathrm{ECO}}$, gross primary production GPP, net ecosystem exchange $\mathrm{NEE}_{\text {and }} \mathrm{CH}_{4}-\mathrm{C}$ exchange) of the net ecosystem carbon balance (NECB) at the intensively used grassland (GI), extensively used grassland (GE) and the natural wetland (NW) site in different measuring periods (07/08, 08/09 and 2008 denotes 1 July 2007-30 June 2008, 1 July 2008 to 30 June 2009, and the calendar year 2008, respectively). Additionally, annual $\mathrm{N}_{2} \mathrm{O}-\mathrm{N}$ exchange is displayed. GWP is summed up considering NEE, manuring, cutting, $\mathrm{CH}_{4}-\mathrm{C}$ and $\mathrm{N}_{2} \mathrm{O}-\mathrm{N}$ exchange. 2007 IPCC standards (Forster et al., 2007) were used with a radiative forcing factor of $25 \mathrm{for}^{\mathrm{CH}} \mathrm{H}_{4}$ and 298 for $\mathrm{N}_{2} \mathrm{O}$ related to $\mathrm{CO}_{2}$ and a time horizon of $100 \mathrm{yr}$; values were converted into atomic mass of $\mathrm{CO}_{2}-\mathrm{C}, \mathrm{CH}_{4}-\mathrm{C}$ and $\mathrm{N}_{2} \mathrm{O}-\mathrm{N}$. The total contribution of $\mathrm{N}_{2} \mathrm{O}-\mathrm{N}$ and $\mathrm{CH}_{4}-\mathrm{C}$ to GWP in $\mathrm{g} \mathrm{CO}_{2}-\mathrm{C}$ equivalents $\mathrm{m}^{-2}$ is shown in the last two columns. Note that small differences from the NEE sum are due to rounding; for clarity the units for $\mathrm{CH}_{4}-\mathrm{C}$ and $\mathrm{N}_{2} \mathrm{O}-\mathrm{N}$ are given in $\mathrm{mg} \mathrm{m}^{-2}$ compared to the others. Errors are displayed as explained in Sect. 2.5.

\begin{tabular}{|c|c|c|c|c|c|c|c|c|c|}
\hline $\begin{array}{l}\text { Site/ } \\
\text { period }\end{array}$ & $\begin{array}{l}R_{\mathrm{ECO}} \\
\left(\mathrm{g} \mathrm{m}^{-2}\right)\end{array}$ & $\begin{array}{l}\text { GPP } \\
\left(\mathrm{g} \mathrm{m}^{-2}\right)\end{array}$ & $\begin{array}{l}\mathrm{NEE} \\
\left(\mathrm{g} \mathrm{m}^{-2}\right)\end{array}$ & $\begin{array}{l}\mathrm{CH}_{4}-\mathrm{C} \\
\left(\mathrm{mg} \mathrm{m}^{-2}\right)\end{array}$ & $\begin{array}{l}\mathrm{NECB} \\
\left(\mathrm{gC} \mathrm{m}^{-2}\right)\end{array}$ & $\begin{array}{l}\mathrm{N}_{2} \mathrm{O}-\mathrm{N} \\
\left(\mathrm{mg} \mathrm{m}^{-2}\right)\end{array}$ & $\begin{array}{l}\mathrm{GWP} \\
\left(\mathrm{g} \mathrm{CO}_{2}-\mathrm{C}\right. \\
\left.\text {-equi } \mathrm{m}^{-2}\right)\end{array}$ & $\begin{array}{l}\mathrm{N}_{2} \mathrm{O}-\mathrm{N} \\
\left(\mathrm{g} \mathrm{CO}_{2}-\mathrm{C}-\right. \\
\text { equi m } \\
-2\end{array}$ & $\begin{array}{l}\mathrm{CH}_{4}-\mathrm{C} \\
\left(\mathrm{g} \mathrm{CO}_{2}-\mathrm{C}-\right. \\
\left.\text { equi m}{ }^{-2}\right)\end{array}$ \\
\hline GI08/09 & $2403 \pm 142$ & $-1921 \pm 190$ & $482 \pm 238$ & $73 \pm 51$ & $817 \pm 238$ & $255 \pm 101$ & $850 \pm 238$ & $33 \pm 13$ & $1 \pm 0$ \\
\hline GI2008 & $2239 \pm 99$ & $-1935 \pm 175$ & $304 \pm 201$ & $248 \pm 346$ & $434 \pm 201$ & $39 \pm 12$ & $441 \pm 201$ & $5 \pm 1$ & $2 \pm 3$ \\
\hline GE07/08 & $1206 \pm 127$ & $-1355 \pm 193$ & $-148 \pm 231$ & $1518 \pm 740$ & $-147 \pm 231$ & $43 \pm 34$ & $-129 \pm 231$ & $5 \pm 4$ & $14 \pm 7$ \\
\hline NW07/08 & $702 \pm 75$ & $-709 \pm 88$ & $-8 \pm 116$ & $5674 \pm 978$ & $-2 \pm 116$ & $9 \pm 11$ & $45 \pm 117$ & $1 \pm 1$ & $52 \pm 9$ \\
\hline NW08/09 & $502 \pm 53$ & $-629 \pm 76$ & $-127 \pm 92$ & $2761 \pm 255$ & $-124 \pm 92$ & $7 \pm 24$ & $-101 \pm 93$ & $1 \pm 3$ & $25 \pm 2$ \\
\hline NW2008 & $617 \pm 38$ & $-630 \pm 64$ & $-14 \pm 75$ & $4672 \pm 635$ & $-9 \pm 75$ & $17 \pm 8$ & $31 \pm 75$ & $2 \pm 1$ & $42 \pm 6$ \\
\hline
\end{tabular}

The highest annual emissions of $\mathrm{CH}_{4}$ were detected at the NW site with $5674 \pm 978 \mathrm{mg} \mathrm{CH}_{4}-\mathrm{C} \mathrm{m}^{-2} \mathrm{yr}^{-1}$ in $2007 / 2008$ and $2761 \pm 255 \mathrm{mg} \mathrm{CH}_{4}-\mathrm{C} \mathrm{m}^{-2} \mathrm{yr}^{-1}$ in $2008 / 2009$. At all sites, methane emissions were higher in the first study year compared to the second year (Fig. 4).

\subsection{Nitrous oxide exchange}

$\mathrm{N}_{2} \mathrm{O}$ fluxes showed high spatial variability at all sites (Fig. 4). Generally, $\mathrm{N}_{2} \mathrm{O}$ fluxes exhibited erratic emission patterns and could not be related to the recorded environmental parameters (soil temperature, soil humidity, water table). $\mathrm{N}_{2} \mathrm{O}$ emissions followed a seasonal pattern at the GI and GE sites with relatively higher $\mathrm{N}_{2} \mathrm{O}$ release in the beginning of September 2007, in summer 2008, and during winter/spring 2009 at GI and with emission peaks in October 2007, and some smaller ones in summer 2008 and winter/spring 2009 at GE (Fig. 4). In contrast, seasonality of $\mathrm{N}_{2} \mathrm{O}$ fluxes was not detected at the $\mathrm{NW}$ site, where no $\mathrm{N}_{2} \mathrm{O}$ emissions were recorded until the summer of 2008 .

The GI site had the highest $\mathrm{N}_{2} \mathrm{O}$ emissions with $115 \pm 78 \mathrm{mg} \mathrm{N}_{2} \mathrm{O}-\mathrm{N} \mathrm{m}^{-2} \mathrm{yr}^{-1}$ in $2007 / 08$ and $255 \pm 101 \mathrm{mg} \mathrm{N}_{2} \mathrm{O}-\mathrm{N} \mathrm{m}^{-2} \mathrm{yr}^{-1}$ in $2008 / 09$. The magnitude of $\mathrm{N}_{2} \mathrm{O}$ fluxes at the $\mathrm{GE}$ site ranged between those of the other two sites, with $43 \pm 34 \mathrm{mg} \mathrm{N}_{2} \mathrm{O}-\mathrm{N} \mathrm{m}^{-2} \mathrm{yr}^{-1}$ in $2007 / 08$ and $31 \pm 24 \mathrm{mg} \mathrm{N}_{2} \mathrm{O}-\mathrm{N} \mathrm{m}^{-2} \mathrm{yr}^{-1}$ in $2008 / 09$. The NW site released no measurable $\mathrm{N}_{2} \mathrm{O}-\mathrm{N}$ in both years with $9 \pm 11 \mathrm{mg} \mathrm{N}_{2} \mathrm{O}-\mathrm{N} \mathrm{m}^{-2} \mathrm{yr}^{-1}$ in the first and $7 \pm 24 \mathrm{mg} \mathrm{N}_{2} \mathrm{O}-\mathrm{N} \mathrm{m}^{-2} \mathrm{yr}^{-1}$ in the second year.

\subsection{Global warming potential}

The GWP of the sites clearly decreased with decreasing anthropogenic impact (i.e. GI $>$ GE $>$ NW, Table 3). However, shifting the annual period to integrate the annual GWP (Fig. 5) led to considerable variation in annual GWP (Table 2, Fig. 5). This was most distinct for the GI site - the average GWP of $850 \pm 238 \mathrm{~g} \mathrm{CO}_{2}-\mathrm{C}$ equivalents $\mathrm{m}^{-2} \mathrm{yr}^{-1}$ for the 08/09 period is almost double the average GWP of $441 \pm 201 \mathrm{~g} \mathrm{CO}_{2}-\mathrm{C}$ equivalents $\mathrm{m}^{-2} \mathrm{yr}^{-1}$ for the calendar year 2008. For the other two sites, changing the integration period caused the sites to shift from being sources to being sinks for all three major greenhouse gases (Table 2, Fig. 5).

\section{Discussion}

\subsection{NECB and NEE}

At the drained, intensively used grassland site (GI) NECB including carbon input by manuring, carbon output by cutting and methane emissions was $434 \pm 201 \mathrm{~g} \mathrm{CO}_{2}-\mathrm{C} \mathrm{m}^{-2} \mathrm{yr}^{-1}$ in 2008. It is well known that deeply drained peatlands emit only negligible amounts of methane-bound carbon. They can even react as small $\mathrm{CH}_{4}-\mathrm{C}$ sinks (Couwenberg et al., 2011). Our results approve these findings as methane emissions amount only to $248 \pm 346 \mathrm{mg} \mathrm{CH}_{4}-\mathrm{C} \mathrm{m}^{-2} \mathrm{yr}^{-1}$ (Table 2). Overall the NECB of the GI site is in line with recently published results. For instance, Veenendaal et al. (2007) reported a NECB of $\sim 420 \mathrm{~g} \mathrm{C} \mathrm{m}^{-2} \mathrm{yr}^{-1}$ from intensively used grassland on peat in the Netherlands. Couwenberg et al. (2011) summarized several studies and came up with annual emission rates of $410-760 \mathrm{~g} \mathrm{CO}_{2}-\mathrm{C} \mathrm{m}^{-2} \mathrm{yr}^{-1}$ from temperate 


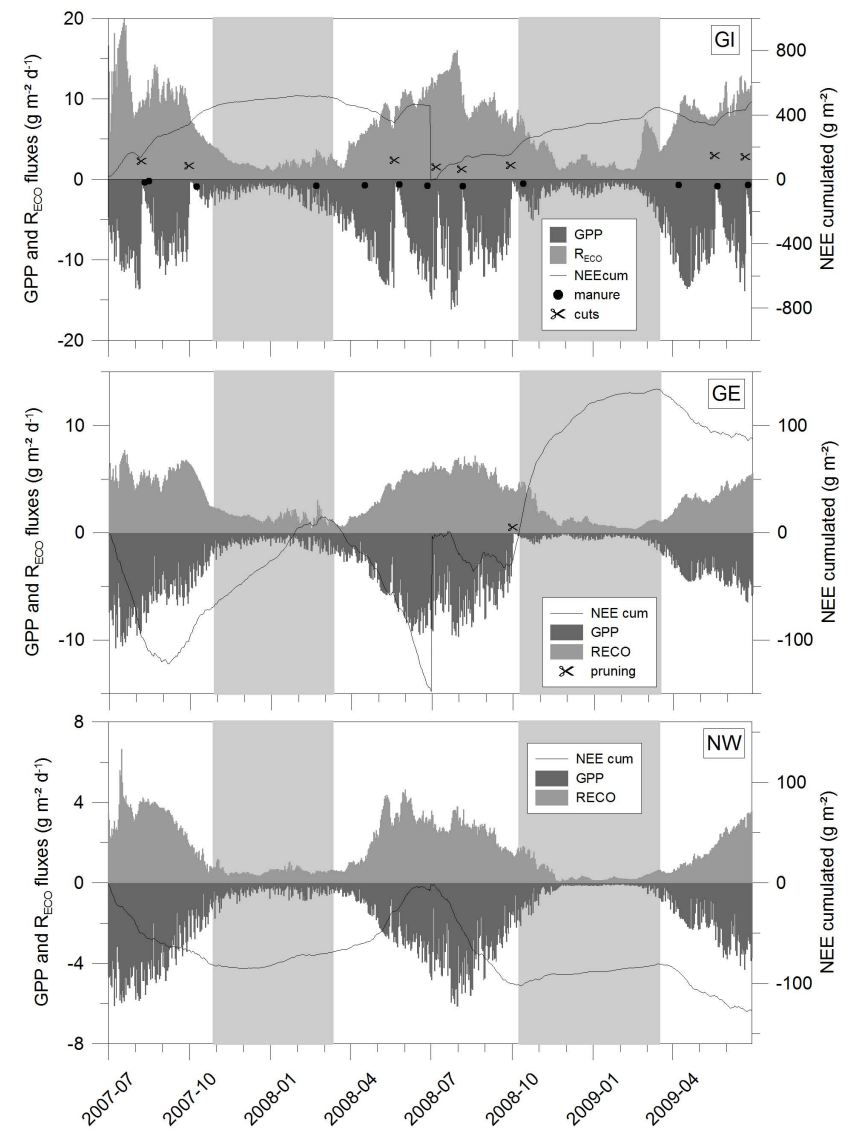

Fig. 3. Modelled $\mathrm{CO}_{2}$ exchange during $2 \mathrm{yr}$ of measurement. $R_{\mathrm{ECO}}$ is above, GPP below zero at the left y-scale. The black line refers to cumulative NEE, which is displayed at the right y-scale. After one year (end of June 2008), NEE is reset to zero. White background represents the growing season; grey background the non-growing season.

grasslands. Note that these values refer to pure $\mathrm{CO}_{2}-\mathrm{C}$ exchange and do not incorporate $\mathrm{CH}_{4}$ exchange like our NECB estimates do. Most of the NECB as well as its interannual variability of the GI site can be explained by land use intensity: the higher frequency of cutting led to much higher emission rates in the second year (5 cuts) than in the first year (3 cuts; Table 3 ). However, when taking only NEE into account, the two years do not differ significantly in their annual $\mathrm{CO}_{2}-\mathrm{C}$ exchange (permutation test, significance of difference of means $=0.33$ ). These findings are in line with Schmitt et al. (2010), who investigated a similarly treated mountain grassland and stated that land use and management have a large impact on NEE.

Another indication of the anthropogenic influence is the time it takes for the site to become a net $\mathrm{CO}_{2}$ sink again after biomass removal by cutting (Wohlfahrt et al., 2008). When biomass is removed from the site, overall leaf area - and consequently GPP - decreases substantially (Schmitt et al., 2010). On average the GI site started to accumulate

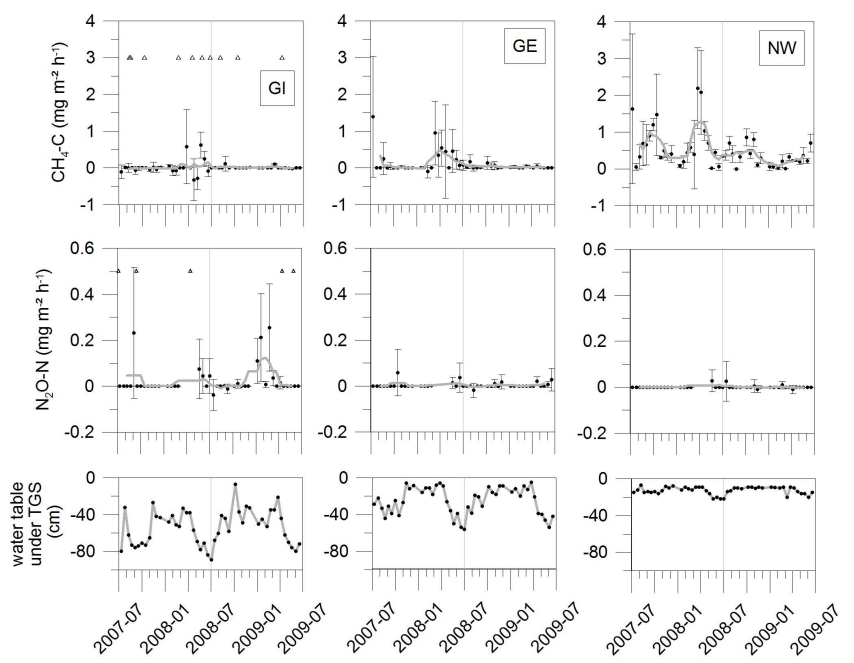

Fig. 4. $\mathrm{CH}_{4}-\mathrm{C}$ (top) and $\mathrm{N}_{2} \mathrm{O}-\mathrm{N}$ exchange (middle) and water table (bottom) during the measuring period (from the left to the right the intensively used site GI, the extensive one GE, and the natural peat bog site NW). TGS denotes the top ground surface. Values are displayed as mean \pm standard deviation of the three replicates. We had to neglect the $\mathrm{N}_{2} \mathrm{O}$ data between $02 / 28 / 08-05 / 20 / 08$ because of problems with the gas chromatograph. The grey line symbolizes the running average of 5 values. The triangles in the left column typify (a) manuring applications for $\mathrm{CH}_{4}$ and (b) fertilizer applications for $\mathrm{N}_{2} \mathrm{O}$.
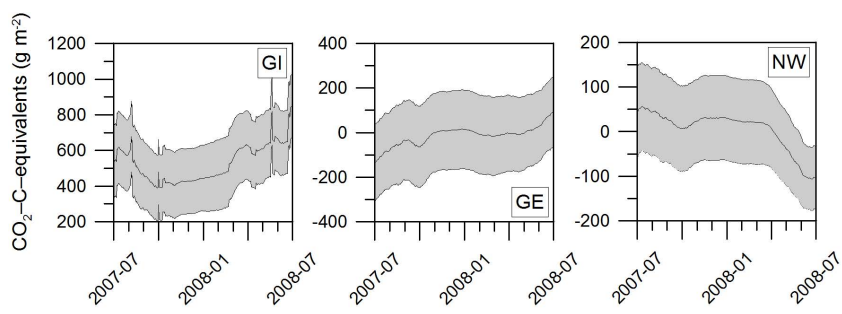

Fig. 5. Annual GWP for 365 days with respect to a shifting period of time. The $\mathrm{x}$-axis shows the start date of the respective integration period. The shaded area displays the cumulated standard deviation, which is calculated as the sum of the daily standard error of $R_{\mathrm{ECO}}$ and GPP models and the standard error of the $\mathrm{CH}_{4} / \mathrm{N}_{2} \mathrm{O}$ emission values.

carbon 22 days after cutting (i.e. after Eq. 2 GPP exceeds $R_{\mathrm{ECO}}$, and NEE values become negative). The GI site was cut 8 times during the whole measuring period, leading to $\mathrm{CO}_{2}$ net emissions at 176 days - approximately $40 \%$ of the total 437 growing season days. Therefore, the NEE of the site was mainly controlled by the cutting regime. Additionally, there were 12 manuring events on the site that possibly had an influence on GPP (and thereby on NEE) because of leaf contamination or cover. Typically, a large part of applied manure respires quickly (Veenendaal et al., 2007). Further, the respiration resulting from manure rather contributes to $\mathrm{C}$ export from the ecosystem and therefore leads to increased 
Table 3. Composition of the NECB at the intensive grassland site of the Ahlen-Falkenberger peat bog. The number of management interventions is shown in parentheses. Note that cuts are defined as carbon loss (positive sign) while manuring is defined as carbon gain (negative sign). Small differences in the sums are due to rounding errors.

\begin{tabular}{llllll}
\hline Year & $\begin{array}{l}\mathrm{NEE} \\
\left(\mathrm{g} \mathrm{m}^{-2}\right)\end{array}$ & $\begin{array}{l}\text { Cuts } \\
\left(\mathrm{g} \mathrm{m}^{-2}\right)\end{array}$ & $\begin{array}{l}\text { Manuring } \\
\left(\mathrm{g} \mathrm{m}^{-2}\right)\end{array}$ & $\begin{array}{l}\mathrm{CH}_{4}-\mathrm{C} \\
\left(\mathrm{mg} \mathrm{m}^{-2}\right)\end{array}$ & $\begin{array}{l}\mathrm{NECB} \\
\left(\mathrm{g} \mathrm{m}^{-2}\right)\end{array}$ \\
\hline$\sum 2007 / 08$ & 458 & $317(3)$ & $-226(7)$ & $146 \pm 354$ & $548 \pm 169$ \\
$\sum 2008 / 09$ & 482 & $515(5)$ & $-181(5)$ & $73 \pm 51$ & $817 \pm 140$ \\
\hline
\end{tabular}

NEE, NECB, and GWP. Therefore, although we could not quantify the manure related fluxes directly, an even stronger differentiation between the GI and the two other sites is to be expected.

The rewetted, extensively used site (GE) was approximately neutral with regard to carbon storage/release in both years $\left(-147 \pm 231 \mathrm{~g} \mathrm{C} \mathrm{m}^{-2} \mathrm{yr}^{-1}\right.$ and $\left.88 \pm 200 \mathrm{~g} \mathrm{C} \mathrm{m}^{-2} \mathrm{yr}^{-1}\right)$. In the literature it is also not clear whether rewetted peatland acts as carbon source or sink when considering NECB. For example, Hendriks et al. (2007) reported that an abandoned peat meadow in the Netherlands is a sink with an NECB of $-280 \pm 78 \mathrm{~g} \mathrm{C} \mathrm{m}^{-2} \mathrm{yr}^{-1}$, whereas Maljanen et al. (2010b) found rewetted peatlands in Finland to be carbon sources, storing 57 to $101 \mathrm{~g} \mathrm{C} \mathrm{m}^{-2} \mathrm{yr}^{-1}$ (based on data from three restored peat bogs). However, compared to the intensively used grassland site (GI), there is a distinct decrease in $\mathrm{C}$ emissions as $\mathrm{CO}_{2}-\mathrm{C}$ and $\mathrm{CH}_{4}-\mathrm{C}$ at the $\mathrm{GE}$ site (Fig. 3). Also, when considering NEE instead of NECB the GE site was more or less neutral with respect to carbon storage/release. However, there was a difference between 2007/08 and 2008/09 $\left(-148 \pm 231\right.$ and $88 \pm 200 \mathrm{~g} \mathrm{CO}_{2}-$ $\mathrm{C} \mathrm{m}^{-2} \mathrm{yr}^{-1}$, respectively), which was probably due to a single cutting event in the second year (1 October 2008, Fig. 3), whereas in the first year there were no cuttings. While GPP is distinctly reduced (to near zero) after cutting events, $R_{\mathrm{ECO}}$ is largely unaffected by cuttings, which presumably caused the difference in the NEE between the two years. Due to the inter-annual variability and the large uncertainties, only long-term measurements spanning several years can clarify whether a given site accumulates C (Roulet et al., 2007).

The natural site (NW) also had an NECB close to zero both in the 1st measuring period 2007/2008 with $-2 \pm 116 \mathrm{~g} \mathrm{C} \mathrm{m}^{-2} \mathrm{yr}^{-1}$, and for calendar year 2008 with $-9 \pm 75 \mathrm{~g} \mathrm{C} \mathrm{m}^{-2} \mathrm{yr}^{-1}$. Contrastingly, the site accumulated $-124 \pm 92 \mathrm{~g} \mathrm{Cm}^{-2} \mathrm{yr}^{-1}$ in the 2 nd measuring period 2008/2009 (Table 2). These amounts of NECB are in line with other studies. For instance, Waddington and Roulet (2000) report a small carbon release from 18 to $32 \mathrm{~g} \mathrm{C} \mathrm{m}^{-2} \mathrm{yr}^{-1}$ from an eccentric raised bog in Sweden. In contrast, Roulet et al. (2007) give C storage rates of $-36.5 \mathrm{~g} \mathrm{C} \mathrm{m}^{-2} \mathrm{yr}^{-1}$ as a 6-yr mean from a northern om-
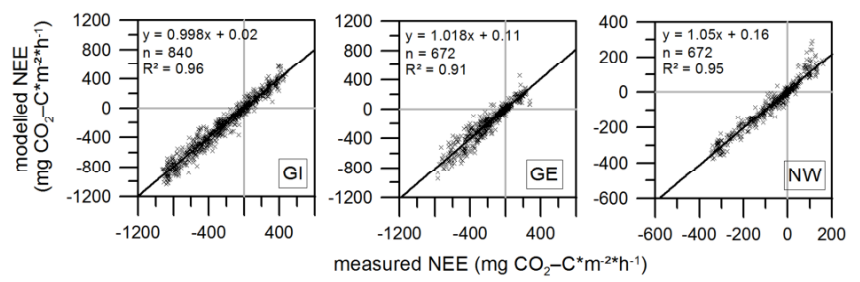

Fig. 6. Scatter plots for NEE model validation. Note the small underestimation at the GI and the slight overestimation at the GE and NW sites.

brotrophic bog in Ontario/Canada (only from gaseous $\mathrm{CO}_{2}$ and $\mathrm{CH}_{4}$ fluxes). Overall our findings are consistent with the assertion that peat bogs are atmospherically neutral or small sinks when only gaseous $\mathrm{CO}_{2}$ and $\mathrm{CH}_{4}$ fluxes are taken into account (Byrne et al., 2004; Drösler et al., 2008, Figs. 3 and 6).

\section{$4.2 \mathrm{CH}_{4}$ fluxes}

At the GI site, $\mathrm{CH}_{4}-\mathrm{C}$ emissions were generally low, presumably due to the relatively low water table, especially during summer ( $65 \pm 18 \mathrm{~cm} 07 / 08,53 \pm 22 \mathrm{~cm} \mathrm{08/09,} \mathrm{Fig.} \mathrm{4).} \mathrm{In}$ general, low water tables cause methanogenic processes to be suppressed, while methanotrophic processes gain importance (Langeveld et al., 1997). Deeply drained peat bogs can even react as $\mathrm{CH}_{4}-\mathrm{C}$ sinks (Maljanen, 2003; Couwenberg et al., 2011). Therefore, the main source for $\mathrm{CH}_{4}-\mathrm{C}$ emissions at the GI site is probably manuring, which is known to cause great temporal and spatial variation of methane fluxes (Flessa and Beese, 2000). Methane emission peaks typically occur immediately (6-48 h) after manure application (Chadwick et al., 2000; Augustin, 2001; Sherlock et al., 2002; Rodhe et al., 2006). We did not find any peaks after manuring, presumably because we strictly followed a bi-weekly cycle of measurements. Therefore, our annual estimates of $\mathrm{CH}_{4}-\mathrm{C}$ exchange are rather conservative and possibly they would be higher if peaks after manuring were to have been taken into account (Jones et al., 2005).

At the GE site, $\mathrm{CH}_{4}-\mathrm{C}$ emissions were relatively high. This was likely caused by the raised water level, which is widely reported to increase methane emissions (Dalal and Allen, 2008). Hendriks et al. (2007) reported similar effects from an abandoned peat meadow in the Netherlands, but the annual $\mathrm{CH}_{4}-\mathrm{C}$ emission rates were about 8 times higher than ours $\left(19 \pm 16 \mathrm{~g} \mathrm{CH}_{4}-\mathrm{C} \mathrm{m}^{-2} \mathrm{yr}^{-1}\right.$ in 2005 and $15 \pm 12 \mathrm{~g} \mathrm{CH}_{4}-\mathrm{C} \mathrm{m}^{-2} \mathrm{yr}^{-1}$ in 2006). These relatively high emissions at the Dutch site are likely caused by the more eutrophic soil characteristics compared with the Ahlenmoor site.

The highest $\mathrm{CH}_{4}-\mathrm{C}$ fluxes and the highest variability in $\mathrm{CH}_{4}-\mathrm{C}$ fluxes were found at the NW site. This is in line with ranges reported in other studies. In a review Saarnio et al. (2007) reported annual methane emissions from 
0.2 to $16.4 \mathrm{~g} \mathrm{CH}_{4}-\mathrm{Cm}^{-2} \mathrm{yr}^{-1}$, with a mean of $4.6 \mathrm{~g} \mathrm{CH}_{4}-$ $\mathrm{C} \mathrm{m}^{-2} \mathrm{yr}^{-1}$ from 26 pristine peat bogs in Finland. Höper et al. (2008) reported an annual emission of $19.4 \mathrm{~g} \mathrm{CH}_{4-}$ $\mathrm{C} \mathrm{m}^{-2} \mathrm{yr}^{-1}$ from a natural peat bog in southern Germany. Methane emissions are often characterized by seasonal patterns (e.g. Flessa et al., 1998; Borken and Beese, 2006). Since methanogenic bacteria can only survive in anoxic conditions, the depth of the aerobic zone greatly influences $\mathrm{CH}_{4}$ emissions, and water table depth is generally the most important variable that controls $\mathrm{CH}_{4}$ fluxes (Roulet et al., 1992; Tuittila et al., 2000). In line with this, the seasonal pattern with highest emissions in winter (of both years) is probably due to the higher water levels in winter compared with the summer season (Fig. 4).

\section{3 $\quad \mathrm{N}_{2} \mathrm{O}$ fluxes}

Although the GI site was the largest source of $\mathrm{N}_{2} \mathrm{O}$ among the studied sites, the annual sum of emissions ( $39 \pm 12 \mathrm{mg} \mathrm{N}_{2} \mathrm{O}-\mathrm{N} \mathrm{m}^{-2} \mathrm{yr}^{-1}$ ) was low compared to similar studies (Byrne et al., 2004: $1000 \mathrm{mg} \mathrm{N}_{2} \mathrm{O}-\mathrm{N} \mathrm{m}^{-2} \mathrm{yr}^{-1}$; Regina et al., 2004: $730 \mathrm{mg} \mathrm{N}_{2} \mathrm{O}-\mathrm{N} \mathrm{m}^{-2} \mathrm{yr}^{-1}$, Maljanen et al., 2004: $300 \mathrm{mg} \mathrm{N}_{2} \mathrm{O}-\mathrm{N} \mathrm{m}^{-2} \mathrm{yr}^{-1}$ ). At the GE and NW sites, $\mathrm{N}_{2} \mathrm{O}$ flux rates were even lower, and characterized by an erratic temporal pattern, which is typical for nutrient-poor peat bogs (Urban et al., 2011).

Presumably, only a small part of the fertilizer at the GI site was transformed into $\mathrm{N}_{2} \mathrm{O}$. Kaiser et al. (1998) found a relative loss from fertilizer as $\mathrm{N}_{2} \mathrm{O}$ emissions of $0.7-4.1 \%$ on a loamy silt soil with winter wheat. Velthof and Oenema (1995) reported $3.9 \%$ loss for a peat soil under grassland, and the IPCC (2006) assumes a global emission factor of $1 \%$ for $\mathrm{N}_{2} \mathrm{O}$ emissions from $\mathrm{N}$ fertilizer. With a total fertilization rate of $11.7 \mathrm{~g} \mathrm{~N} \mathrm{~m}^{-2} \mathrm{yr}^{-1}$ in the first and $12.1 \mathrm{~g} \mathrm{~N} \mathrm{~m}^{-2} \mathrm{yr}^{-1}$ in the second year, the $\mathrm{N}_{2} \mathrm{O}$ emissions from the GI site are in line with the IPCC global emission factor $(1.0 \%$ in the first and $2.1 \%$ in the second year). Unlike others (e.g. Chadwick et al., 2000, or Augustin, 2001), we detected no significant peaks after fertilizer applications. Thus, it is likely that a part of $\mathrm{N}_{2} \mathrm{O}$ emissions is derived from mineralization of organic substance triggered by weather conditions. For example, from January to April 2009, we detected a slight superficial ground frost at the climate station although soil temperature did not fall below zero. Hence, superficial freezethaw cycles may explain the higher emissions during that time (Christensen and Christensen, 1991; Flessa et al., 1998; Teepe et al., 2001).

$\mathrm{N}_{2} \mathrm{O}$ budgets that are based on temporal upscaling of momentary observations risk missing $\mathrm{N}_{2} \mathrm{O}$ emission peaks that originate from fertilizer or manure application. However, even very short measurement intervals do not guarantee recording of all emission peaks due to the extremely high temporal (Kaiser et al., 1998) and spatial (Folorunso and Rolston, 1984; Glatzel et al., 2008) variation of $\mathrm{N}_{2} \mathrm{O}$ fluxes. Furthermore, if we really missed peak fluxes, the difference be- tween the intensive site and the other sites would be even higher than reported here. Therefore, the annual estimates of $\mathrm{N}_{2} \mathrm{O}$ exchange at the GI site are rather conservative.

\subsection{GWP}

Annual estimates of GWP varied significantly between sites. GWP decreased linearly with intensity of land use in both study periods 2007/2008 and 2008/2009. When considering the calendar year 2008 the gradient is less apparent. While the GI site was still the biggest source as expected, both the natural and the extensively used sites exhibited similar annual GWP around zero. This suggests that rewetting improves the GWP of drained peat bogs to a near-natural state. This may be less pronounced when several years are taken into account to provide longer-term annual averages that level out inter-annual variability because GWP seems to not only depend on the intensity of land use and depth of drainage, but also on the exact period used for deriving the annual estimates.

We investigated two years of measurements, each running from July to June, which allowed us to evaluate the influence of the period on the annual estimate. In many other studies, different periods are used to obtain annual estimates. For example, Hendriks et al. (2007) used regular calendar years, Veenendaal et al. (2007) estimated annual balances based on data from October to September, and Lund et al. (2007) used data of a period from August to July. Other studies used only the months of the growing season to estimate annual emissions (Tuittila et al., 2000, 2004; Kivimäki et al., 2008; Teh et al., 2011). The choice of the exact period for deriving GHG or GWP balances can have a large influence on the resulting annual estimate (Fig. 5). Especially at the GI site, emissions are apparently lower when considering only the calendar year 2008 compared with other integration intervals, which is likely caused be varying intensity of agricultural measures during the respective period. But also natural variability - for instance in climate - may cause significant differences in annual estimates of GHG exchange: see e.g. Lafleur et al. (2003), who found that an ombrotrophic peatland in Canada was a significantly smaller $\mathrm{CO}_{2}$ sink in a drier year compared to wetter years. We suggest that annual estimates of GWP should be based on several years of GHG exchange data, especially when the values are used for extrapolations to the regional scale (Roulet et al., 2007; Drösler et al., 2008), because otherwise the regional estimates may be based on spurious data and do not average out inter-annual variability.

\subsection{Limitations}

Despite high model accuracy in our data (Fig. 6), there are some limitations regarding our estimates. First, we used only soil temperature for modelling $R_{\mathrm{ECO}}$. Some studies show significant relationships with other parameters like soil moisture 
or water table depth (e.g. Wilson et al., 2007), but since we found no improvement of fit when using these parameters, we used the simpler model.

Second, we interpolated the modelling parameters linearly between measurement dates by fitting the models against the measured fluxes. With this approach fluxes may be overestimated because forage plants initially grow more slowly directly after cutting. After this initial phase, growth rates increase linearly until the genetically determined capacity is reached (Horrocks and Valentine, 1999). However, in most studies the model parameters are determined using measurements from several field days. Therefore, the parameters are then used for modelling of GPP for much longer time spans. Here we used relatively short time steps (3-4 weeks) to represent the changing driving parameters through cutting, manuring, or changing weather conditions. The higher frequency of field measurements leads to more flexible modelling with regard to the adaptation of changing environmental parameters.

Another aspect is the temperature range and the time span used to model $R_{\mathrm{ECO}}$. Other studies refer to year-round measurements (Ojanen et al., 2010) to model $R_{\mathrm{ECO}}$, which increases the fit of the model but decreases the sensitivity to the environmental drivers. We attempted to create one model for each measuring day. However, the smaller the temperature range for any given day, the more difficult it is to fit significant modelling parameters. To avoid this problem, we pooled data from some of the winter measurements to increase the range of the included temperatures and the reliability of the models.

Furthermore, we did not consider lateral losses of dissolved carbon. By considering these amounts, the loss of $C$ (i.e. NECB) could be even higher than found here. For example, Schulze et al. (2009) reported $7 \pm 3 \mathrm{~g} \mathrm{C} \mathrm{m}^{-2} \mathrm{yr}^{-1}$ loss from European grasslands, Hendriks et al. (2007) found $20.6 \pm 4.3 \mathrm{~g}$ dissolved $\mathrm{C} \mathrm{m}^{-2} \mathrm{yr}^{-1}$ outgoing in water from an abandoned peatland in the Netherlands, while Worrall and Evans (2009) gave a total dissolved carbon loss of $17.3 \mathrm{~g} \mathrm{C} \mathrm{m}^{-2} \mathrm{yr}^{-1}$ from upland peat soils. These examples show that the proportion of dissolved carbon loss from total carbon fluxes is usually rather low, and by not considering this flux the total error incurred is probably negligible.

Finally, we may have missed possible peaks of methane or nitrous oxide emission following manure application or weather events (heavy rain or freeze-thaw events) because we strictly followed a bi-weekly measurement routine. The possibly missed peaks only would have strengthened our findings that the GI site had a significantly higher GWP than the GE and NW sites with respect to $\mathrm{N}_{2} \mathrm{O}-\mathrm{N}$. With respect to $\mathrm{C}$ exchange in form of $\mathrm{CH}_{4}$ we may indeed have missed peaks after extreme weather events at the GE and NW sites. Nevertheless, the permanently high water table at these sites renders specifically high emissions after heavy rain unlikely because the top peat is saturated with water year round and water table is the most important control on methane emissions (Whalen, 2005; Dalal and Allen, 2008; Lai, 2009).
After all, gathering gas flux data with chamber-based approaches involves considerable measurement effort. Therefore, it was not justified to intensify the measurements.

\section{Conclusions}

Only full greenhouse gas balances allow for the thorough evaluation of the success of restoration measures in terms of GWP. Extensification - in our case, the treatment of the site with a maximum of one cut per year and the increase of the water level to an annual average of approximately $30 \mathrm{~cm}$ below ground - can already lead to a considerable reduction of the GWP. This can be mainly attributed to decreased carbon oxidation of the peat due to the higher water level. However, by the same token, methane emissions are increased. This reduction in GWP can only be seen as a first step. The ultimate goal of restoration measures from the point of view of nature protection should be to bring drained and exploited peat bogs to near-natural conditions, since only under near-natural conditions these areas will be able to accumulate carbon at longer timescales, i.e. centuries. For shorter timescales like years to decades, the rewetting and extensification of these areas can be a useful step enhancing their carbon balance. This suggestion is supported by the fact that the annual GWP varied considerably, depending on the temporal boundaries of the integration period. Therefore, it is crucial to study several years to understand and acknowledge the influence of natural inter-annual variability. Naturally high inter-annual variability greatly compromises GWP balances based on data series that span a year or less, severely decreasing their reliability. Comparable integration periods should be used, especially in review articles and meta-analyses that bring together many datasets to derive generalizable GWP values for ecosystems or vegetation types.

Despite the limitations of the chamber method, we think that chamber-based comparisons of GWP estimates can provide a valuable contribution to closing the data gap of full GHG balances of peat bogs with varying land use history and intensity in central Europe because of the possibility to attribute GHG exchange directly to small-scale land use patterns. Therefore, we need to further develop the methodology especially with regard to modelling and uncertainty analysis. To our knowledge, this is the first chamber-based GWP study that provides a thorough analysis of uncertainty. 
Table A1. Model parameters of the intensively used grassland site (GI). Note the reset of GP $\max$ to 0.01 and $\alpha$ to 0.0001 after every cut. $E_{0}, R_{\text {ref }}, \mathrm{GP}_{\max }$ and $\alpha$ indicate the activation energy-like parameter $(\mathrm{K})$, the reference temperature $(\mathrm{K})$, highest possible production rate at infinite PAR ( $\left.\mathrm{mg} \mathrm{CO}_{2}-\mathrm{C} \mathrm{m}^{-2} \mathrm{~h}^{-1}\right)$ and initial slope of the regression curve $\left(\left(\mathrm{mg} \mathrm{CO}_{2}-\mathrm{C} \mathrm{m}^{-2} \mathrm{~h}^{-1}\right) /\left(\mu \mathrm{mol} \mathrm{m}{ }^{-2} \mathrm{~s}^{-1}\right)\right)$, respectively. " $R$ ECOse", "GPP-se", " $n_{\mathrm{R}}$ " and " $n_{\mathrm{G}}$ " display the standard error for the daily $R_{\mathrm{ECO}}$ model, the standard error for the daily GPP model, the number of measurements for $R_{\mathrm{ECO}}$ (with opaque chambers, see Sect. 2.2), and the number of measurements for GPP (with transparent chambers, see Sect. 2.2), respectively. Interpolated or reset values do not possess a number of measurement.

\begin{tabular}{|c|c|c|c|c|c|c|c|c|}
\hline Date & $E_{0}$ & $R_{\text {ref }}$ & $R_{\mathrm{ECO}}-\mathrm{se}$ & $n_{\mathrm{R}}$ & $\mathrm{GP}_{\max }$ & $\alpha$ & GPP-se & $n_{\mathrm{G}}$ \\
\hline $07-06-26$ & 558.6847 & 2.5108 & 1.3384 & 15 & -30.2707 & -0.0496 & 2.0852 & 24 \\
\hline $07-06-26$ & 558.6847 & 2.5108 & 1.3384 & & -0.0100 & -0.0001 & 0.0000 & \\
\hline $07-07-03$ & 1471.3662 & 0.2862 & 1.2098 & 12 & -25.2983 & -0.0417 & 2.7461 & 30 \\
\hline 07-07-31 & 135.3197 & 6.2981 & 0.3755 & 14 & -37.9017 & -0.0687 & 1.7427 & 29 \\
\hline 07-08-08 & 135.3197 & 6.2981 & 0.3755 & & -37.9017 & -0.0687 & 1.7427 & \\
\hline 07-08-08 & 135.3197 & 6.2981 & 0.3755 & & -0.0100 & -0.0001 & 0.0000 & \\
\hline $07-08-28$ & 634.2096 & 3.6860 & 1.3878 & 15 & -42.7841 & -0.0628 & 2.0958 & 29 \\
\hline $07-09-25$ & 289.1930 & 7.0702 & 0.8702 & 18 & -33.9845 & -0.0969 & 1.2487 & 25 \\
\hline $07-10-01$ & 289.1930 & 7.0702 & 0.8702 & & -33.9845 & -0.0969 & 1.2487 & \\
\hline $07-10-01$ & 274.0827 & 6.5935 & 0.4422 & & -0.0100 & -0.0001 & 0.0000 & \\
\hline $07-10-23$ & 274.0827 & 6.5935 & 0.4422 & 17 & -23.9211 & -0.0303 & 1.3718 & 19 \\
\hline $07-11-20$ & 378.3950 & 3.7155 & 0.1447 & 20 & -44.2141 & -0.0323 & 0.5837 & 29 \\
\hline $07-12-19$ & 378.3950 & 3.7155 & 0.1447 & 20 & -27.9100 & -0.0354 & 0.5403 & 29 \\
\hline $08-01-23$ & 605.4808 & 6.1323 & 0.0690 & 12 & -27.4635 & -0.0343 & 0.9595 & 30 \\
\hline 08-02-19 & 424.6452 & 7.0000 & 0.1321 & 10 & -21.2762 & -0.0418 & 0.9831 & 30 \\
\hline 08-03-18 & 800.8235 & 9.5561 & 0.5603 & 11 & -22.9285 & -0.0440 & 2.7638 & 21 \\
\hline 08-04-15 & 319.4286 & 9.0466 & 0.8761 & 12 & -31.4535 & -0.0450 & 1.7474 & 24 \\
\hline 08-05-14 & 240.4213 & 5.9488 & 0.3344 & 15 & -51.7233 & -0.0453 & 1.7061 & 36 \\
\hline $08-05-21$ & 240.4213 & 5.9488 & 0.3344 & & -51.7233 & -0.0453 & 1.7061 & \\
\hline $08-05-21$ & 151.3368 & 7.7737 & 1.2024 & & -0.0100 & -0.0001 & 0.0000 & \\
\hline $08-06-10$ & 151.3368 & 7.7737 & 1.2024 & 16 & -38.7669 & -0.0285 & 1.8164 & 29 \\
\hline 08-07-08 & 474.9224 & 4.4294 & 1.4597 & 15 & -38.8842 & -0.0777 & 2.0904 & 27 \\
\hline 08-07-08 & 167.4792 & 8.9999 & 0.2804 & 29 & -0.0100 & -0.0001 & 0.0000 & 59 \\
\hline 08-07-15 & 167.4792 & 8.9999 & 0.2804 & 29 & -76.4232 & -0.0370 & 1.6260 & 59 \\
\hline 08-08-05 & 659.3573 & 2.7229 & 1.3499 & 17 & -43.6556 & -0.0707 & 1.5413 & 30 \\
\hline 08-08-05 & 773.7294 & 1.7302 & 0.7448 & & -0.0100 & -0.0001 & 0.0000 & \\
\hline 08-08-13 & 773.7294 & 1.7302 & 0.7448 & 42 & -36.3505 & -0.0490 & 1.4127 & 72 \\
\hline 08-09-04 & 503.4891 & 4.2383 & 1.4954 & 15 & -36.9798 & -0.0921 & 1.4302 & 24 \\
\hline 08-09-30 & 529.8864 & 4.8680 & 0.9101 & 12 & -40.4232 & -0.0649 & 1.9138 & 21 \\
\hline 08-09-30 & 648.1739 & 4.9236 & 0.5295 & & -0.0100 & -0.0001 & 0.0000 & \\
\hline $08-10-28$ & 648.1739 & 4.9236 & 0.5295 & 9 & -31.6413 & -0.0665 & 0.7994 & 18 \\
\hline $08-11-25$ & 935.4821 & 19.1376 & 0.1870 & 9 & -12.7987 & -0.0144 & 0.6061 & 18 \\
\hline $08-12-16$ & 615.6713 & 10.4065 & 0.1748 & 8 & -32.6280 & -0.0514 & 0.7080 & 18 \\
\hline 09-01-27 & 1019.1616 & 23.3732 & 0.3189 & 28 & -16.1900 & -0.0137 & 0.2721 & 17 \\
\hline 09-02-17 & 1019.1665 & 23.3735 & 0.3189 & 28 & -5.5158 & -0.0194 & 0.3115 & 24 \\
\hline 09-03-17 & 70.4089 & 3.3621 & 0.4566 & 15 & -15.4270 & -0.0941 & 1.5594 & 24 \\
\hline 09-04-15 & 173.4907 & 8.5886 & 1.0984 & 15 & -44.1163 & -0.0819 & 1.9671 & 30 \\
\hline 09-05-12 & 207.1945 & 6.3262 & 1.0940 & 18 & -27.7155 & -0.0558 & 2.0005 & 24 \\
\hline 09-05-19 & 207.1945 & 6.3262 & 1.0940 & & -27.7155 & -0.0558 & 2.0005 & \\
\hline 09-05-19 & 207.1945 & 6.3262 & 1.0940 & & -0.0100 & -0.0001 & 0.0000 & \\
\hline 09-06-09 & 646.1311 & 3.8604 & 0.6061 & 12 & -45.3028 & -0.0398 & 1.3252 & 57 \\
\hline 09-06-23 & 430.4646 & 5.6422 & 2.1633 & 17 & -51.3333 & -0.0425 & 2.2379 & 27 \\
\hline $09-06-23$ & 430.4646 & 5.6422 & 2.1633 & & -0.0100 & -0.0001 & 0.0000 & \\
\hline
\end{tabular}


Table A2. Model parameters of the extensively used grassland site (GE). For explanation of the parameters see caption of Table A1.

\begin{tabular}{|c|c|c|c|c|c|c|c|c|}
\hline Date & $\mathrm{E}_{0}$ & $R_{\text {ref }}$ & $R_{\mathrm{ECO}}-\mathrm{se}$ & $n_{\mathrm{R}}$ & $\mathrm{GP}_{\max }$ & $\alpha$ & GPP-se & $n_{\mathrm{G}}$ \\
\hline $2007-06-05$ & 606.6137 & 2.0376 & 1.5039 & 15 & -34.2379 & -0.0721 & 1.9021 & 24 \\
\hline $2007-07-03$ & 898.5615 & 0.9300 & 1.4033 & 11 & -35.0000 & -0.0376 & 2.1428 & 30 \\
\hline $2007-07-31$ & 239.4467 & 2.8306 & 0.4876 & 14 & -23.8098 & -0.0617 & 1.4147 & 28 \\
\hline $2007-08-28$ & 497.4610 & 1.6753 & 0.3513 & 15 & -21.3167 & -0.0352 & 1.9182 & 28 \\
\hline $2007-09-25$ & 69.2081 & 5.8602 & 0.4747 & 13 & -21.7029 & -0.0727 & 1.9729 & 29 \\
\hline $2007-10-23$ & 282.1348 & 3.7173 & 0.1938 & 16 & -14.5059 & -0.0335 & 1.1190 & 20 \\
\hline $2007-11-20$ & 376.0437 & 2.9089 & 0.0888 & 21 & -18.1556 & -0.0260 & 0.4250 & 31 \\
\hline $2007-12-19$ & 376.0437 & 2.9089 & 0.0888 & 21 & -18.1556 & -0.0260 & 0.4250 & 31 \\
\hline $2008-01-23$ & 490.1077 & 4.7712 & 0.1824 & 12 & -14.5733 & -0.0165 & 0.4225 & 29 \\
\hline 2008-02-19 & 629.7390 & 4.5212 & 0.1267 & 12 & -20.3500 & -0.0112 & 0.3129 & 29 \\
\hline 2008-03-18 & 891.0012 & 3.7559 & 0.1264 & 9 & -8.5184 & -0.0188 & 0.8900 & 16 \\
\hline 2008-04-15 & 264.4537 & 2.3891 & 0.2207 & 12 & -21.8429 & -0.0097 & 1.1492 & 27 \\
\hline $2008-05-14$ & 293.4065 & 2.4873 & 0.4625 & 15 & -16.7160 & -0.0286 & 1.3742 & 36 \\
\hline $2008-06-10$ & 133.8097 & 4.1508 & 0.8648 & 18 & -22.2911 & -0.0488 & 2.2552 & 33 \\
\hline 2008-07-08 & 263.5043 & 3.1262 & 0.5734 & 15 & -35.5896 & -0.0228 & 1.9639 & 27 \\
\hline 2008-08-05 & 191.4129 & 3.7999 & 0.7630 & 18 & -34.8994 & -0.0381 & 2.1353 & 29 \\
\hline 2008-09-04 & 841.3845 & 1.4153 & 0.6383 & 15 & -36.6889 & -0.0339 & 2.4220 & 24 \\
\hline 2008-09-30 & 136.2680 & 3.6905 & 0.2126 & 12 & -40.1481 & -0.0264 & 2.1347 & 21 \\
\hline $2008-10-01$ & 136.2680 & 3.6905 & 0.2126 & & -40.1481 & -0.0264 & 2.1347 & \\
\hline $2008-10-01$ & 136.2680 & 3.6905 & 0.2126 & & -0.0100 & -0.0001 & 0.0000 & \\
\hline $2008-10-28$ & 894.7987 & 2.6317 & 0.1822 & 9 & -5.2702 & -0.0193 & 0.4324 & 18 \\
\hline $2008-11-25$ & 232.6695 & 1.1594 & 0.0589 & 9 & -6.7700 & -0.0029 & 0.2336 & 18 \\
\hline $2008-12-16$ & 1074.7713 & 9.5859 & 0.1131 & 9 & -7.3718 & -0.0185 & 0.2704 & 18 \\
\hline 2009-01-27 & 496.6910 & 1.5241 & 0.0844 & 21 & -4.6300 & -0.0076 & 0.1358 & 18 \\
\hline $2009-02-17$ & 931.3856 & 5.1844 & 0.0358 & 12 & -3.1586 & -0.0068 & 0.2215 & 24 \\
\hline $2009-03-17$ & 157.9131 & 1.0787 & 0.1920 & 15 & -5.4980 & -0.0249 & 0.4690 & 24 \\
\hline $2009-04-15$ & 298.9361 & 2.6648 & 0.6504 & 15 & -10.2877 & -0.0574 & 1.0953 & 30 \\
\hline $2009-05-12$ & 285.8882 & 2.0238 & 0.5375 & 18 & -11.4815 & -0.0168 & 0.8577 & 24 \\
\hline $2009-06-23$ & 262.3326 & 3.1967 & 0.7736 & 18 & -15.6453 & -0.0320 & 2.3909 & 30 \\
\hline
\end{tabular}

Table A3. Model parameters for the natural wetland site (NW). For explanation of the parameters see caption of Table A1.

\begin{tabular}{lllllllll}
\hline Date & $E_{0}$ & $R_{\text {ref }}$ & $R_{\mathrm{ECO}}-\mathrm{se}$ & $n_{\mathrm{R}}$ & $\mathrm{GP}_{\max }$ & $\alpha$ & GPP-se & $n_{\mathrm{G}}$ \\
\hline $2007-06-06$ & 612.2000 & 1.3412 & 0.8448 & 12 & -16.8466 & -0.0332 & 1.4487 & 32 \\
$2007-07-04$ & 952.2000 & 0.4327 & 0.4248 & 12 & -14.2179 & -0.0371 & 1.1126 & 35 \\
$2007-08-01$ & 371.4969 & 2.0069 & 0.2940 & 18 & -13.9601 & -0.0392 & 0.5615 & 31 \\
$2007-08-29$ & 15.8083 & 3.5286 & 0.2829 & 15 & -12.7185 & -0.0469 & 0.7660 & 30 \\
$2007-09-26$ & 377.7793 & 1.7031 & 0.3224 & 15 & -15.3146 & -0.0229 & 0.5967 & 29 \\
$2007-10-24$ & 425.1539 & 1.0766 & 0.0563 & 38 & -10.4295 & -0.0207 & 0.2449 & 27 \\
$2007-11-21$ & 425.1539 & 1.0766 & 0.0563 & 38 & -23.4013 & -0.0126 & 0.1908 & 39 \\
$2007-12-20$ & 425.1539 & 1.0766 & 0.0563 & 38 & -23.4005 & -0.0126 & 0.1877 & 39 \\
$2008-01-24$ & 286.0344 & 0.7242 & 0.0697 & 12 & -20.0000 & -0.0095 & 0.0832 & 15 \\
$2008-02-20$ & 204.2522 & 0.6690 & 0.0579 & 11 & -3.5140 & -0.0063 & 0.0816 & 21 \\
$2008-03-19$ & 227.3249 & 0.8725 & 0.1098 & 12 & -7.0000 & -0.0020 & 0.2512 & 20 \\
$2008-04-16$ & 301.3850 & 1.8693 & 0.2137 & 12 & -5.7310 & -0.0047 & 0.6503 & 30 \\
$2008-05-15$ & 418.2503 & 2.5189 & 0.5783 & 15 & -11.1375 & -0.0097 & 0.9763 & 34 \\
$2008-06-11$ & 264.3127 & 2.2490 & 0.4950 & 14 & -14.1495 & -0.0091 & 1.2910 & 24 \\
$2008-07-09$ & 350.1843 & 1.2635 & 0.2065 & 18 & -16.3709 & -0.0185 & 0.6258 & 27 \\
$2008-08-06$ & 553.3654 & 0.8043 & 0.3233 & 15 & -24.6306 & -0.0226 & 0.8120 & 24 \\
$2008-09-05$ & 591.2674 & 1.2502 & 0.2921 & 12 & -14.4967 & -0.0290 & 0.6426 & 24 \\
$2008-10-01$ & 356.2749 & 1.1864 & 0.0995 & 12 & -11.4941 & -0.0202 & 0.3713 & 21 \\
$2008-10-29$ & 829.5494 & 1.1870 & 0.0700 & 12 & -11.7124 & -0.0125 & 0.3015 & 15 \\
$2008-11-26$ & 757.4883 & 0.7628 & 0.0239 & 7 & -0.7571 & -0.0084 & 0.1402 & 18 \\
$2008-12-17$ & 1344.6000 & 3.0204 & 0.0491 & 17 & -0.5750 & -0.0151 & 0.1462 & 33 \\
$2009-01-28$ & 634.6977 & 1.4341 & 0.0552 & 21 & -0.5430 & -0.0034 & 0.1166 & 39 \\
$2009-02-18$ & 634.6977 & 1.4344 & 0.0552 & 21 & -0.5430 & -0.0034 & 0.1166 & 39 \\
$2009-03-18$ & 131.9624 & 0.8173 & 0.0683 & 15 & -8.9052 & -0.0035 & 0.2473 & 27 \\
$2009-04-16$ & 752.2716 & 0.7689 & 0.1692 & 15 & -8.8081 & -0.0086 & 0.3198 & 27 \\
$2009-05-13$ & 250.5506 & 1.4783 & 0.2563 & 18 & -24.4454 & -0.0046 & 0.6667 & 27 \\
$2009-06-24$ & 130.6848 & 2.7956 & 0.3320 & 21 & -12.9192 & -0.0160 & 0.8237 & 27 \\
\hline & & & & & & & &
\end{tabular}


Acknowledgements. We want to thank the Federal Ministry of Education and Research (BMBF) of Germany for funding the project "Strategies for Peatland Management" and Paul Stoy as well as four anonymous referees for very helpful comments to improve the quality of this work.

Edited by: P. Stoy

\section{References}

Alm, J., Saarnio, S., Nykanen, H., Silvola, J., and Martikainen, P.: Winter $\mathrm{CO}_{2}, \mathrm{CH}_{4}$, and $\mathrm{N}_{2} \mathrm{O}$ fluxes on some boreal natural and drained peatlands, Biogeochemistry, 44, 163-186, 1999.

Alm, J., Shurpali, N. J., Minkkinen, K., Aro, L., Hytönen, J., Laurila, T., Lohila, A., Maljanen, M., Martikainen, P. J., and Makiranta, P.: Emission factors and their uncertainty for the exchange of $\mathrm{CO}_{2}, \mathrm{CH}_{4}$ and $\mathrm{N}_{2} \mathrm{O}$ in Finnish managed peatlands, Boreal Environ. Res., 12, 191-209, 2007.

Augustin, J.: Emission, Aufnahme und Klimarelevanz von Spurengasen, in: Landschaftsökologische Moorkunde, zweite Auflage, edited by: Succow, M. and Joosten, H., E. Schweizerbarth, Stuttgart, 28-37, 2001.

Bellisario, L. M., Bubier, J. L., Moore, T. R., and Chanton, J. P.: Controls on $\mathrm{CH}_{4}$ emissions from a northern peatland, Global Biogeochem. Cy., 13, 81-91, 1999.

Blodau, C.: Carbon cycling in peatlands A review of processes and controls, Environ. Rev., 10, 111-134, 2002.

Borken, W. and Beese, F.: Methane and nitrous oxide fluxes of soils in pure and mixed stands of European beech and Norway spruce, Eur. J. Soil Sci., 57, 617-625, 2006.

Byrne, K. A., Chojnicki, B., Christensen, T. R., Drösler, M., Freibauer, A., Friborg, T., Frolking, S., Lindroth, A., Mailhammer, J., Malmer, N., Selin, P., Turunen, J., Valentini, R., and Zetterberg, L.: EU peatlands: Current carbon stocks and trace gas fluxes, Carbo-Europe-GHG Concerted Action-Synthesis of the European Greenhouse Gas Budget, Report, 4, 2004, 2004.

Chadwick, D. R., Pain, B. F., and Brookman, S. K. E.: Nitrous oxide and methane emissions following application of animal manures to grassland, J. Environ. Qual, 29, 277-287, 2000.

Chapin, F. S., Woodwell, G. M., Randerson, J. T., Rastetter, E. B., Lovett, G. M., Baldocchi, D. D., Clark, D. A., Harmon, M. E., Schimel, D. S., Valentini, R., Wirth, C., Aber, J. D., Cole, J. J., Goulden, M. L., Harden, J. W., Heimann, M., Howarth, R. W., Matson, P. A., McGuire, A. D., Melillo, J. M., Mooney, H. A., Neff, J. C., Houghton, R. A., Pace, M. L., Ryan, M. G., Running, S. W., Sala, O. E., Schlesinger, W. H., and Schulze, E.-D.: Reconciling Carbon-cycle Concepts, Terminology, and Methods, Ecosystems, 9, 1041-1050, 2006.

Christensen, S. and Christensen, B. T.: Organic matter available for denitrification in different soil fractions: effect of freeze/thaw cycles and straw disposal, J. Soil Sci., 42, 637-647, 1991.

Couwenberg, J.: Greenhouse gas emissions from managed peat soils: is the IPCC reporting guidance realistic, Mires and Peat, 8, 1-10, 2011.

Dalal, R. C. and Allen, D. E.: Turner Review No. 18, Greenhouse gas fluxes from natural ecosystems, Aust. J. Bot., 56, 369-407, 2008.

Dalal, R. C., Allen, D. E., Livesley, S. J., and Richards, G.: Magnitude and biophysical regulators of methane emission and con- sumption in the Australian agricultural, forest, and submerged landscapes: a review, Plant Soil, 309, 43-76, 2007.

Drösler, M.: Trace gas exchange and climatic relevance of bog ecosystems, Southern Germany, 2005.

Drösler, M., Freibauer, A., Christensen, T. R., and Friborg, T.: Observations and status of peatland greenhouse gas emissions in Europe, The Continental-Scale Greenhouse Gas Balance of Europe, 243-261, 2008.

Efron, B. and Tibshirani, R. J.: An introduction to the bootstrap, Chapman \& Hall/CRC., 1994.

Elsgaard, L., Görres, C. M., Hoffmann, C. C., Blicher-Mathiesen, G., Schelde, K., and Petersen, S. O.: Net ecosystem exchange of $\mathrm{CO}_{2}$ and carbon balance for eight temperate organic soils under agricultural management, Agr. Ecosyst. Environ., 162, 5267, 2012.

Flessa, H. and Beese, F.: Laboratory estimates of trace gas emissions following surface application and injection of cattle slurry, J.Environ. Qual., 29, 262-268, 2000.

Flessa, H., Wild, U., Klemisch, M., and Pfadenhauer, J.: Nitrous oxide and methane fluxes from organic soils under agriculture, Eur. J.Soil Sci., 49, 327-335, 1998.

Folorunso, O. A. and Rolston, D. E.: Spatial variability of fieldmeasured denitrification gas fluxes, Soil Sci. Soc. Am. J., 48, 1214-1219, 1984.

Forster, P., Ramaswamy, V., Artaxo, P., Berntsen, T., Betts, R., Fahey, D. W., Haywood, J., Lean, J., Lowe, D. C., Myhre, G., Nganga, J., Prinn, R., Raga, G., Schulz, M., and Van Dorland, R.: Changes in Atmospheric Constituents and in Radiative Forcing, in: Climate Change 2007: The Physical Science Basis. Contribution of Working Group I to the Fourth Assessment Report of the Intergovernmental Panel on Climate Change, edited by: Solomon, S., Qin, D., Manning, M., Chen, Z., Marquis, M., Averyt, K. B., Tignor, M., and Miller, H. L., Cambridge University Press, Cambridge, United Kingdom and New York, NY, USA, 2007.

Glatzel, S., Forbrich, I., Krüger, C., Lemke, S., and Gerold, G.: Small scale controls of greenhouse gas release under elevated $\mathrm{N}$ deposition rates in a restoring peat bog in NW Germany, Biogeosciences, 5, 925-935, doi:10.5194/bg-5-925-2008, 2008.

Gorham, E. and Rochefort, L.: Peatland restoration: a brief assessment with special reference to Sphagnum bogs, Wetl. Ecol. Manag., 11, 109-119, 2003.

Hall, D. O. and Rao, K. K.: Photosynthesis (6th Edn), Studies in Biology, Cambridge, Cambridge University Press, 1999.

Hargreaves, K. J. and Fowler, D.: Quantifying the effects of water table and soil temperature on the emission of methane from peat wetland at the field scale, Atmos. Environ., 32, 3275-3282, 1998.

Hendriks, D. M. D., van Huissteden, J., Dolman, A. J., and van der Molen, M. K.: The full greenhouse gas balance of an abandoned peat meadow, Biogeosciences, 4, 411-424, doi:10.5194/bg-4411-2007, 2007.

Höper, H.: Freisetzung von Treibhausgasen aus deutschen Mooren, Telma, 37, 85-116, 2007.

Höper, H., Augustin, J., Cagampan, J. P., Drösler, M., Lundin, L., Moors, E. J., Vasander, H., Waddington, J. M., Wilson, D.: Restoration of peatlands and greenhouse gas balances, in: Peatlands and Climate Change. edited by: Strack, D. M., International Peat Society, Jyvaskyla, 182-210, 2008. 
Horrocks, R. D. and Valentine, J. F.: Harvested forages, Academic Press, 1999.

IPCC: IPCC Guidelines for National Greenhouse Gas Inventories, prepared by the National Greenhouse Gas Inventories Programme, edited by: Eggleston, H. S, Buendia, L., Miwa, K., Ngara, T., and Tanabe, K., Volume 4, Chapter 11, $\mathrm{N}_{2} \mathrm{O}$ emissions from managed soils, and $\mathrm{CO}_{2}$ emissions from lime and urea application, IGES, Hayama, Japan, 2006.

Iqbal, J., Lin, S., Hu, R., and Feng, M.: Temporal variability of soil-atmospheric $\mathrm{CO}_{2}$ and $\mathrm{CH}_{4}$ fluxes from different land uses in mid-subtropical China, Atmos. Environ., 43, 5865-5875, 2009.

Janssens, W.: Defining the vegetation period by temperature sums, in: Proceedings of the 7th Conference on Biometeorology, Freiburg, 312-318, 2010.

Jassal, R. S., Black, T. A., Roy, R., and Ethier, G.: Effect of nitrogen fertilization on soil $\mathrm{CH}_{4}$ and $\mathrm{N}_{2} \mathrm{O}$ fluxes, and soil and bole respiration, Geoderma, 162, 182-186, 2011.

Jones, S. K., Rees, R. M., Skiba, U. M., and Ball, B. C.: Greenhouse gas emissions from a managed grassland, Global Planet. Change, 47, 201-211, 2005.

Jungkunst, H. F. and Fiedler, S.: Latitudinal differentiated water table control of carbon dioxide, methane and nitrous oxide fluxes from hydromorphic soils: feedbacks to climate change, Glob. Change Biol., 13, 2668-2683, 2007.

Jungkunst, H. F., Freibauer, A., Neufeldt, H., and Bareth, G.: Nitrous oxide emissions from agricultural land use in Germany - a synthesis of available annual field data, J. Plant Nutr. Soil Sci., 169, 341-351, 2006.

Jungkunst, H. F., Flessa, H., Scherber, C., and Fiedler, S.: Groundwater level controls $\mathrm{CO}_{2}, \mathrm{~N}_{2} \mathrm{O}$ and $\mathrm{CH}_{4}$ fluxes of three different hydromorphic soil types of a temperate forest ecosystem, Soil Biol. Biochem., 40, 2047-2054, 2008.

Kaiser, E. A., Kohrs, K., Kücke, M., Schnug, E., Heinemeyer, O., and Munch, J. C.: Nitrous oxide release from arable soil: importance of $\mathrm{N}$-fertilization, crops and temporal variation, Soil Biol. Biochem., 30, 1553-1563, 1998.

Kasimir-Klemedtsson, ̊̊., Klemedtsson, L., Berglund, K., Martikainen, P., Silvola, J., and Oenema, O.: Greenhouse gas emissions from farmed organic soils: a review, Soil Use Manage., 13, 245-250, 1997.

Kettunen, A., Kaitala, V., Lehtinen, A., Lohila, A., Alm, J., Silvola, J., and Martikainen, P. J.: Methane production and oxidation potentials in relation to water table fluctuations in two boreal mires, Soil Biol. Biochem., 31, 1741-1749, 1999.

Kivimäki, S. K., Yli-Petäys, M., and Tuittila, E.: Carbon sink function of sedge and Sphagnum patches in a restored cut-away peatland: increased functional diversity leads to higher production, J. Appl. Ecol., 45, 921-929, 2008.

Lafleur, P. M., Roulet, N. T., Bubier, J. L., Frolking, S., and Moore, T. R.: Interannual variability in the peatland-atmosphere carbon dioxide exchange at an ombrotrophic bog, Global Biogeochem. Cy., 17, 1036, doi:10.1029/2002GB001983, 2003.

Lai, D. Y. F.: Methane dynamics in northern peatlands: A review, Pedosphere, 19, 409-421, 2009.

Laine, A., Wilson, D., Kiely, G., and Byrne, K. A.: Methane flux dynamics in an Irish lowland blanket bog, Plant Soil, 299, 181193, 2007.

Langeveld, C. A., Segers, R., Dirks, B. O. M., Van den Pol-van Dasselaar, A., Velthof, G. L., and Hensen, A.: Emissions of $\mathrm{CO}_{2}$,
$\mathrm{CH}_{4}$ and $\mathrm{N}_{2} \mathrm{O}$ from pasture on drained peat soils in the Netherlands, Eur. J. Agron., 7, 35-42, 1997.

LGLN (State Office for Geoinformation and land development in Lower Saxony): Excerpts from the geodata in Lower Saxony surveying and cadastral management. Lower Saxony Ministry of Environment, Energy and Climate Change, 2012.

Lloyd, J. and Taylor, J. A.: On the temperature dependence of soil respiration, Funct. Ecol., 8, 315-323, 1994.

Lund, M., Lindroth, A., Christensen, T. R., and Ström, L.: Annual $\mathrm{CO}_{2}$ balance of a temperate bog, Tellus B, 59, 804-811, 2007.

Maljanen, M.: Greenhouse gas dynamics of farmed or forested organic soils in Finland, Kuopion yliopisto, 2003.

Maljanen, M., Hytönen, J., and Martikainen, P. J.: Fluxes of $\mathrm{N}_{2} \mathrm{O}$, $\mathrm{CH}_{4}$ and $\mathrm{CO}_{2}$ on afforested boreal agricultural soils, Plant Soil, 231, 113-121, 2001.

Maljanen, M., Komulainen, V. M., Hytönen, J., Martikainen, P. J., and Laine, J.: Carbon dioxide, nitrous oxide and methane dynamics in boreal organic agricultural soils with different soil characteristics, Soil Biol. Biochem., 36, 1801-1808, 2004.

Maljanen, M., Hytönen, J., and Martikainen, P. J.: Cold-season nitrous oxide dynamics in a drained boreal peatland differ depending on land-use practice, Can. J. Forest Res., 40, 565-572, 2010a.

Maljanen, M., Sigurdsson, B. D., Guðmundsson, J., Óskarsson, H., Huttunen, J. T., and Martikainen, P. J.: Greenhouse gas balances of managed peatlands in the Nordic countries - present knowledge and gaps, Biogeosciences, 7, 2711-2738, doi:10.5194/bg7-2711-2010, 2010b.

Michaelis, L. and Menten, M. L.: Die Kinetik der Invertinwirkung, Biochem. Z., 49, 333-369, 1913.

Moffat, A. M., Papale, D., Reichstein, M., Hollinger, D. Y., Richardson, A. D., Barr, A. G., Beckstein, C., Braswell, B. H., Churkina, G., and Desai, A. R.: Comprehensive comparison of gap-filling techniques for eddy covariance net carbon fluxes, Agr. Forest Meteorol., 147, 209-232, 2007.

Ojanen, P., Minkkinen, K., Alm, J., and Penttilä, T.: Soilatmosphere $\mathrm{CO}_{2}, \mathrm{CH}_{4}$ and $\mathrm{N}_{2} \mathrm{O}$ fluxes in boreal forestry-drained peatlands, Forest Ecol. Manage., 260, 411-421, 2010.

R Development Core Team: A language and environment for statistical computing. R Foundation for Statistical Computing, Vienna, Austria, ISBN 3-900051-07-0, http://www.R-project.org/, 2012.

Regina, K., Syväsalo, E., Hannukkala, A., and Esala, M.: Fluxes of $\mathrm{N}_{2} \mathrm{O}$ from farmed peat soils in Finland, Eur. J. Soil Sci., 55 , 591-599, 2004.

Robertson, G. P.: Greenhouse Gases in Intensive Agriculture: Contributions of Individual Gases to the Radiative Forcing of the Atmosphere, Science, 289, 1922-1925, 2000.

Rochefort, L. and Lode, E.: Restoration of degraded boreal peatlands, Boreal peatland ecosystems, Ecol. Stu., 188, 381-423, 2006.

Rodhe, L., Pell, M., and Yamulki, S.: Nitrous oxide, methane and ammonia emissions following slurry spreading on grassland, Soil Use Manage., 22, 229-237, 2006.

Roulet, N., Moore, T., Bubier, J., and Lafleur, P.: Northern fens: methane flux and climatic change, Tellus B, 44, 100-105, 1992.

Roulet, N. T., Lafleur, P. M., Richard, P. J. H., Moore, T. R., Humphreys, E. R., and Bubier, J.: Contemporary carbon balance and late Holocene carbon accumulation in a northern peatland, Glob. Change Biol., 13, 397-411, 2007. 
Saarnio, S., Morero, M., M., Shurpali, N. J., Tuittila, E. S., Mäkilä, M., and Alm, J.: Annual $\mathrm{CO}_{2}$ and $\mathrm{CH}_{4}$ fluxes of pristine boreal mires as a background for the lifecycle analyses of peat energy, Boreal Environ. Res., 12, 101-113, 2007.

Saarnio, S., Winiwarter, W., and Leitao, J.: Methane release from wetlands and watercourses in Europe, Atmos. Environ., 43, 1421-1429, 2009.

Schils, R., Kuikman, P., Liski, J., Van Oijen, M., Smith, P., Webb, J., Alm, J., Somogyi, Z., Van den Akker, J., and Billett, M.: Review of existing information on the interrelations between soil and climate change, (ClimSoil), Final report, 2008.

Schmitt, M., Bahn, M., Wohlfahrt, G., Tappeiner, U., and Cernusca, A.: Land use affects the net ecosystem $\mathrm{CO}_{2}$ exchange and its components in mountain grasslands, Biogeosciences, 7, 22972309, doi:10.5194/bg-7-2297-2010, 2010.

Schneekloth, H.: Die Moore in Niedersachsen, in: Bereich Der Blätter Neumünster, Helgoland Emden Und Lingen Der Geologischen Karte Der Bundesrepublik Deutschland (1:200000), Kommissionsverlag Göttinger Tageblatt, Göttingen, 1981.

Schröder, W., Holy, M., Pesch, R., Harmens, H., and Fagerli, H.: Mapping background values of atmospheric nitrogen total depositions in Germany based on EMEP deposition modeling and the European Moss Survey 2005, Environ. Sci. Eur., 23, 18, doi:10.1186/2190-4715-23-18, 2011.

Schulze, E. D., Luyssaert, S., Ciais, P., Freibauer, A., Janssens, I. A., Soussana, J. F., Smith, P., Grace, J., Levin, I., Thiruchittampalam, B., Heimann, M., Dolman, A. J., Valentini, R., Bousquet, P., Peylin, P., Peters, W., Rödenbeck, C., Etiope, G., Vuichard, N., Wattenbach, M., Nabuurs, G. J., Poussi, Z., Nieschulzel, J., Gash, J. H. and the CarboEurope Team: Importance of methane and nitrous oxide for Europe's terrestrial greenhouse-gas balance, Nat. Geosci., 2, 842-850, 2009.

Sherlock, R. R., Sommer, S. G., Khan, R. Z., Wood, C., Guertal, E. A., Freney, J. R., Dawson, C. O., and Cameron, K. C.: Ammonia, methane, and nitrous oxide emission from pig slurry applied to a pasture in New Zealand, J. Environ. Qual., 31, 1491-1501, 2002.

Teepe, R., Brumme, R., and Beese, F.: Nitrous oxide emissions from soil during freezing and thawing periods, Soil Biol. Biochem., 33, 1269-1275, 2001.

Teh, Y. A., Silver, W. L., Sonnentag, O., Detto, M., Kelly, M., and Baldocchi, D. D.: Large Greenhouse Gas Emissions from a Temperate Peatland Pasture, Ecosystems, 14, 311-325, 2011.
Tukey, J. W.: Exploratory data analysis, Reading, MA, 231, 1977.

Tuittila, E. S., Komulainen, V. M., Vasander, H., Nykänen, H., Martikainen, P. J., and Laine, J.: Methane dynamics of a restored cut-away peatland, Glob. Change Biol., 6, 569-581, 2000.

Tuittila, E. S., Vasander, H., and Laine, J.: Sensitivity of C Sequestration in Reintroduced Sphagnum to Water-Level Variation in a Cutaway Peatland, Restor. Ecol., 12, 483-493, 2004.

Urban, N., Verry, E. S., Eisenreich, S., Grigal, D. F., and Sebestyen, S. D.: Element Cycling in Upland/Peatland Watersheds, Peatland Biogeochemistry and Watershed Hydrology at the Marcell Experimental Forest, 213, 2011.

Veenendaal, E. M., Kolle, O., Leffelaar, P. A., Schrier-Uijl, A. P., Van Huissteden, J., Van Walsem, J., Möller, F., and Berendse, F.: $\mathrm{CO}_{2}$ exchange and carbon balance in two grassland sites on eutrophic drained peat soils, Biogeosciences, 4, 1027-1040, doi:10.5194/bg-4-1027-2007, 2007.

Velthof, G. L. and Oenema, O.: Nitrous oxide fluxes from grassland in the Netherlands: II. Effects of soil type, nitrogen fertilizer application and grazing, Eur. J. Soil Sci., 46, 541-549, 1995.

Waddington, J. M. and Roulet, N. T.: Carbon balance of a boreal patterned peatland, Glob. Change Biol., 6, 87-97, 2000.

Whalen, S. C.: Biogeochemistry of methane exchange between natural wetlands and the atmosphere, Environ. Eng. Sci., 22, 73-94, 2005.

Wilson, D., Tuittila, E. S., Alm, J., Laine, J., Farrell, E. P., and Byrne, K. A.: Carbon dioxide dynamics of a restored maritime peatland, Ecoscience, 14, 71-80, 2007.

Wilson, D., Alm, J., Laine, J., Byrne, K. A., Farrell, E. P., and Tuittila, E.-S.: Rewetting of Cutaway Peatlands: Are We Re-Creating Hot Spots of Methane Emissions?, Restor. Ecol., 17, 796-806, 2009.

Wohlfahrt, G., Hammerle, A., Haslwanter, A., Bahn, M., Tappeiner, U., and Cernusca, A.: Seasonal and inter-annual variability of the net ecosystem $\mathrm{CO}_{2}$ exchange of a temperate mountain grassland: effects of weather and management, J. Geophys. Res., 113, D08110, doi:10.1029/2008GL035090, 2008.

Worrall, F. and Evans, M. G.: The carbon budget of upland peat soils, in: Drivers of Environmental Change in Uplands, Routledge, Taylor \& Francis Group, Abingdon, 2, 93-112, 2009.

Zedler, J. B. and Kercher, S.: Wetland resources: status, trends, ecosystem services, and restorability, Annu. Rev. Env. Resour., 30, 39-74, 2005. 